



\section{Pilots naar de vermindering van fijnstofemissie uit pluimveestallen: absoluutfilters van Inno ${ }^{+} /$Plettenburg}

Yvo Goselink, Hilko Ellen, Jos Huis in 't Veld, Albert Winkel 
Goselink, Y., H. Ellen, J. Huis in 't Veld, A. Winkel, 2020. Pilots naar de vermindering van fijnstofemissie uit pluimveestallen: absoluutfilters van Inno ${ }^{+} /$Plettenburg. Wageningen Livestock Research, Rapport 1244.

Samenvatting NL Om de blootstelling aan fijnstof in veehouderijgebieden te verlagen zijn technieken nodig die de emissie uit pluimveestallen kunnen verminderen. In deze pilot zijn metingen verricht aan de absoluutfilters van Inno+/Plettenburg, geïnstalleerd in een leghennenstal. In afwijking van de meetprotocollen is er in de zogenaamde "fijnstof pilots" aan één (in plaats van twee) bedrijfslocaties gemeten. Uit de metingen blijkt dat het systeem de emissie van fijnstof $\left(\mathrm{PM}_{10}\right)$ met gemiddeld $76 \%$ vermindert. Door leklucht te minimaliseren is waarschijnlijk een hoger reductiepercentage haalbaar.

Summary UK To mitigate the concentrations of fine particulate matter in livestock farming areas, techniques are needed which reduce emissions from poultry barns. In this pilot study, measurements were carried out on the absolute filters from the company Inno+/Plettenburg, installed inside a layer barn. In deviation from the measurement protocols, the so called "fine dust pilots" included one (instead of two) farm locations. The measurements show that the system reduces the emission of fine particulate matter $\left(\mathrm{PM}_{10}\right)$ with $76 \%$. By minimizing leakage air, a higher reduction percentage is probably achievable.

Dit rapport is gratis te downloaden op https://doi.org/10.18174/523912 of op www.wur.nl/livestock-research (onder Wageningen Livestock Research publicaties).

\section{(C) 2020 Wageningen Livestock Research}

Postbus 338, 6700 AH Wageningen, T 03174839 53, E info.livestockresearch@wur.nl, www.wur.nl/livestock-research. Wageningen Livestock Research is onderdeel van Wageningen University \& Research.

Wageningen Livestock Research aanvaardt geen aansprakelijkheid voor eventuele schade voortvloeiend uit het gebruik van de resultaten van dit onderzoek of de toepassing van de adviezen.

Alle rechten voorbehouden. Niets uit deze uitgave mag worden vermenigvuldigd en/of openbaar gemaakt worden door middel van druk, fotokopie, microfilm of op welke wijze dan ook zonder voorafgaande toestemming van de uitgever of auteur.

Wageningen Livestock Research is NEN-EN-ISO 9001:2015 gecertificeerd.

Op al onze onderzoeksopdrachten zijn de Algemene Voorwaarden van de Animal Sciences Group van toepassing. Deze zijn gedeponeerd bij de Arrondissementsrechtbank Zwolle. 


\section{Inhoud}

$\begin{array}{ll}\text { Woord vooraf } & 5\end{array}$

$\begin{array}{ll}\text { Samenvatting } & 7\end{array}$

1

\begin{tabular}{l|l} 
Inleiding & 8
\end{tabular}

$\begin{array}{lll}1.1 & \text { Wetenschappelijke probleembeschrijving } & 8\end{array}$

$\begin{array}{lll}1.2 & \text { Aanleiding } & 8\end{array}$

$\begin{array}{lll}1.3 & \text { Afbakening en doelstelling } & 9\end{array}$

$\begin{array}{lll}1.4 & \text { Opzet rapport } & 9\end{array}$

$2 \quad$ Materiaal en methoden $\quad 10$

$\begin{array}{lll}2.1 & \text { Beschrijving techniek en werkingsprincipe } & 10\end{array}$

2.2 Beschrijving stal en bedrijfssituatie $\quad 11$

2.3 Meetstrategie 11

2.4 Meetmethoden 13

2.4.1 Fijnstof $\left(\mathrm{PM}_{10}\right) \quad 13$

2.4.2 Ventilatiedebiet $\quad 14$

2.4.3 Temperatuur en relatieve luchtvochtigheid 14

2.4.4 Productiegegevens 14

2.5 Dataverwerking en analyse $\quad 14$

2.5.1 Berekening ventilatiedebiet $\quad 14$

2.5.2 Berekening fijnstofemissie $\quad 15$

2.5.3 Berekening eindreductiepercentage fijnstofemissie met bandbreedte $\quad 15$

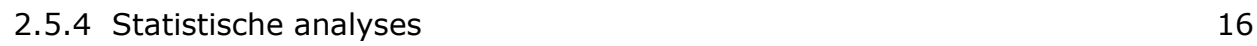

$\begin{array}{llr}3 & \text { Resultaten } & 17\end{array}$

$\begin{array}{lll}3.1 & \text { Meetomstandigheden } & 17\end{array}$

$3.2 \mathrm{CO}_{2}$-concentratie en ventilatiedebiet $\quad 19$

$\begin{array}{ll}3.3 \text { Concentratie, emissie en reductie } \mathrm{PM}_{10} & 19\end{array}$

4

$\begin{array}{ll}\text { Discussie } & \mathbf{2 1}\end{array}$

$5 \quad$ Conclusie $\quad 25$

$\begin{array}{ll}\text { Literatuur } & 26\end{array}$

$\begin{array}{lll}\text { Bijlage } 1 \quad \text { Beschrijving stal } & 28\end{array}$

Bijlage 2 Landbouwkundige voorwaarden 35

Bijlage $3 \quad$ Kalibratie meetapparatuur 36 



\section{Woord vooraf}

In de zoektocht voor pluimveebedrijven naar de mogelijkheden om de emissie van fijnstof ( $\left.P M_{10}\right)$ uit stallen terug te dringen is in de Regio Foodvalley een project bestaande uit een achttal pilots gestart. In de pilots kregen leveranciers van nieuwe technieken of stalsystemen de mogelijkheid om metingen te laten uitvoeren naar de effectiviteit daarvan. De pilots werden uitgevoerd onder de verantwoordelijkheid en organisatie van het Praktijkcentrum Emissiereductie Veehouderij (PEV). Pluimveehouders stelden voor de pilots hun stal beschikbaar als proeflocatie. Wageningen Livestock Research, tenslotte, leverde de wetenschappelijke kennis rondom veehouderijemissies en reductietechnieken, en voerde de metingen in de proefstallen uit. In dit rapport zijn de resultaten van de metingen aan een van de door het PEV geselecteerde technieken weergegeven. We willen de medewerkers van het PEV, het projectteam, de leverancier en de pluimveehouder bedanken voor de fijne en constructieve samenwerking bij de uitvoering van de metingen.

De auteurs 


\title{
Samenvatting
}

\begin{abstract}
Aanleiding en doel
In sommige gebieden in Nederland, zoals in de Foodvalley regio, vormen pluimveestallen een belangrijke emissiebron van fijnstofdeeltjes $\left(\mathrm{PM}_{10}\right)$ in de buitenlucht die geassocieerd worden met gezondheidseffecten bij mensen. In deze pilot is onderzocht in welke mate de absoluutfilters van de firma's Inno ${ }^{+} /$Plettenburg in staat zijn om de emissie van fijnstof uit leghennenstallen te reduceren. Op basis van dit meetrapport kan de techniek worden opgenomen in nationale of regionale regelgeving met een (voorlopig) reductiepercentage voor fijnstof. Ondernemers in de veehouderij kunnen deze techniek vervolgens aanwenden op hun bedrijf om de belasting van de omgeving met fijnstof te verlagen.
\end{abstract}

\section{Fijnstofreductiesysteem en proefstal}

De metingen zijn uitgevoerd in de Kipsterstal te Oirlo, met in totaal 24.000 leghennen. Voordat de ventilatielucht de stal verlaat wordt deze door tien absoluutfilters geleid. Deze absoluutfilters bestaan uit een fijn filtermateriaal dat stofdeeltjes tegenhoudt. Deze techniek met filter is reeds opgenomen in de lijst "E 7 Additionele technieken voor emissiereductie van fijnstof" met $50 \%$ reductie bij gespecificeerde ventilatiedebieten voor de verschillende diercategorieën ( $E, F$ en $G$ ). Het stoffilter heeft volgens de beschrijving in deze lijst (BWL 2020.02) een verwijderingspercentage voor fijnstof (PM10) van 99\%. Om te voorkomen dat de filters verstopt raken worden deze vier tot 12 keer per dag van binnenuit schoon geblazen met behulp van perslucht. Een deel van het stof dat hierbij vrijkomt daalt neer op de bovenste laag van de droogtunnel en wordt hiermee vervolgens afgevoerd.

\section{Meetstrategie en meetmethoden}

In dit onderzoek is een reductiepercentage bepaald door zowel voor als achter het absoluutfilter te meten, op deze beide plekken is de emissie berekend en gemiddeld. Vervolgens is met deze twee getallen een reductiepercentage berekend. Emissie reducerende technieken voor stallen worden normaliter getest volgens het meetprotocol zoals die is opgesteld in Nederland en in het internationale VERA collectief. Deze meetprotocollen zijn zo veel mogelijk gevolgd. In afwijking van de protocollen is er o.a. op één i.p.v. twee bedrijfslocaties gemeten. Geprobeerd werd de metingen gebalanceerd uit te voeren over de productieperiode en het kalenderjaar om een representatieve schatting van de reductie te verkrijgen waarbij invloeden van productiestadium en seizoen zijn meegenomen. De metingen betroffen: temperatuur en relatieve luchtvochtigheid, $\mathrm{CO}_{2}$-concentratie (t.b.v. het berekenen van het ventilatiedebiet middels de $\mathrm{CO}_{2}$-balansmethode) en concentratie van $\mathrm{PM}_{10}$. Uit de combinatie van ventilatiedebiet en $\mathrm{PM}_{10}$-concentratie is de $\mathrm{PM}_{10}$-emissie berekend.

\section{Resultaten}

In totaal werden acht metingen uitgevoerd, die allen gebruikt konden worden voor het bepalen van het reductiepercentage. De gemiddelde $\mathrm{PM}_{10}$ concentratie voor het filter bedroeg $2392 \mu \mathrm{g} / \mathrm{m}^{3}$, versus $520 \mu \mathrm{g} / \mathrm{m}^{3}$ achter het filter. De gemiddelde $\mathrm{PM}_{10}$ emissie uit de stal bedroeg 25,4 g/dier per jaar voor het filter, versus 6,1 g/dier per jaar na het filter. Op basis van deze beide waarden werd de emissie van $\mathrm{PM}_{10}$ statistisch significant verlaagd met gemiddeld $76 \%$.

\section{Conclusie}

De absoluutfilters van de firma's Inno+/Plettenburg zijn in staat de emissie van $\mathrm{PM}_{10}$ vanuit leghennenstallen te reduceren. Op grond van acht metingen voor en achter de absoluutfilters van één leghennenstal, waarbij de relevante meetprotocollen zoveel mogelijk zijn gevolgd, bedraagt deze reductie gemiddeld $76 \%$. Deze reductie is statistisch significant verschillend van nul. Het lagere reductiepercentage dan haalbaar wordt waarschijnlijk voornamelijk veroorzaakt door leklucht tussen de dierruimtes en de drukkamer voor de ventilatoren. Rekening houdend met een onzekerheidsmarge van 10 procentpunten vanwege het meten op slechts één bedrijfslocatie, is het advies om een reductiepercentage op te nemen van $66 \%$. 


\section{$1 \quad$ Inleiding}

\subsection{Wetenschappelijke probleembeschrijving}

Fijnstof, oftewel $\mathrm{PM}_{10}$ is een verzamelnaam voor vaste en vloeibare deeltjes kleiner dan 10 micrometer $^{1}$ die zwevend in de lucht aanwezig zijn (EN 12341:2014; CEN, 2014). Na inademing kunnen deze zeer kleine deeltjes tot diep in de luchtwegen doordringen. Ze kunnen negatieve gezondheidseffecten veroorzaken, zoals een verhoogd risico op het ontstaan en verergeren van aandoeningen aan luchtwegen, longen, hart en bloedvaten. Fijnstof in de buitenlucht is verantwoordelijk voor circa $4 \%$ van de totale ziektelast. Na roken (13\%) behoort luchtverontreiniging daarmee tot één van de belangrijkste risicofactoren (Gezondheidsraad, 2018). Fijnstof is afkomstig van natuurlijke bronnen (zoals bosbranden, winderosie en zeezoutdeeltjes) en van antropogene bronnen zoals het verkeer en transport, de industrie en de agrarische sector. De Europese luchtkwaliteitsrichtlijn 2008/50/EG bevat grenswaarden voor o.a. fijnstof in de buitenlucht. De daggemiddelde concentratie mag maximaal $50 \mu \mathrm{g} / \mathrm{m}^{3}$ bedragen waarbij er jaarlijks maximaal 35 overschrijdingsdagen zijn toegestaan. Daarnaast mag de concentratie van fijnstof jaargemiddeld maximaal $40 \mu \mathrm{g} / \mathrm{m}^{3}$ bedragen. De World Health Organization hanteert een Air Quality Guideline limiet van jaargemiddeld een aanzienlijk lagere $20 \mu \mathrm{g} / \mathrm{m}^{3}$ (WHO, 2005). Er bestaat echter geen drempelwaarde voor de effecten van fijnstof, d.w.z. iedere in de lucht aanwezige microgram fijnstof is slecht voor de gezondheid.

De concentratie en samenstelling van fijnstof in de buitenlucht varieert van moment tot moment (temporele variatie) en van plek tot plek (spatiele variatie). In stedelijke gebieden kan circa tweederde van het in de buitenlucht aanwezige antropogene fijnstof afkomstig zijn van de uitstoot van verkeer en transport, terwijl in het agrarische buitengebied circa de helft van het in de lucht aanwezige antropogene fijnstof afkomstig kan zijn van stalemissies en landbouw (Hendriks et al., 2013). Stallen voor pluimvee, varkens en runderen vormen - na het verkeer en de industrie - de derde emissiebron van fijnstof in Nederland (Winkel et al., 2016). Deze deeltjes ontstaan in stallen vooral uit mest, veren, huid/haren, voer en stro(oisel) (Aarnink et al., 2011). Stalstof verschilt van stedelijk of industrieel stof doordat het van biologische origine is en rijk is aan micro-organismen en resten daarvan, zoals endotoxinen ${ }^{2}$ (Winkel et al, 2014). In Nederland is in de afgelopen jaren daarom gericht onderzoek gedaan naar de gezondheid van omwonenden van veehouderijen die blootstaan aan deze deeltjes. Dit betroffen achtereenvolgens de onderzoeksprojecten "Intensieve Veehouderij en Gezondheid" (Heederik en IJzermans, 2011), "Veehouderij en Gezondheid Omwonenden" (Maassen et al., 2016), "Veehouderij en Gezondheid Omwonenden II" (Hagenaars et al., 2017), "Veehouderij en Gezondheid Omwonenden III (IJzermans et al., 2018) en "Risicomodellering Veehouderij en Gezondheid" (Heederik et al, 2019). Uit deze onderzoeken blijkt dat de blootstelling aan stalstof en het endotoxine daarin geassocieerd is met minder atopie (gevoeligheid voor allergie). Aan de andere kant is de blootstelling geassocieerd met meer klachten en meer medicijngebruik bij omwonenden met $\mathrm{COPD}^{3}$, meer longontstekingen, meer klachten van de luchtwegen en een verlaagde longfunctie.

\section{$1.2 \quad$ Aanleiding}

In de Foodvalley regio, een regio van acht gemeenten ${ }^{4}$ met samen circa 350.000 inwoners, komen relatief hoge concentraties voor van fijnstof, ammoniak $\left(\mathrm{NH}_{3}\right)$ en geur door de aanwezigheid van veel veehouderijbedrijven. Naar aanleiding van de resultaten van de hiervoor genoemde onderzoeken naar de effecten van veehouderijen op de gezondheid van omwonenden zijn in de Regio Foodvalley

\footnotetext{
${ }^{1}$ Eén micrometer $(\mu \mathrm{m})$ is gelijk aan één duizendste millimeter, $10 \mu \mathrm{m}$ is gelijk aan een honderdste millimeter.

2 Endotoxinen zijn celwanddelen van Gram-negatieve bacteriën die sterk ontstekingsbevorderend zijn.

${ }^{3}$ COPD: Chronic Obstructive Pulmonary Disease = Chronische Obstructieve Long Aandoeningen.

${ }^{4}$ De acht gemeenten in de Foodvalley regio zijn: Barneveld, Ede, Nijkerk, Rhenen, Renswoude, Scherpenzeel, Veenendaal en Wageningen.
} 
afspraken gemaakt tussen regionale overheden en de veehouderijsector om de bijdrage van de veehouderij op de luchtkwaliteit in de regio te verminderen. Deze samenwerking is vastgelegd in het Manifest Gezonde Leefomgeving Veehouderij (GLV). De afspraken in het Manifest omvatten grofweg twee sporen:

- Bestuurlijk: optimalisatie/kansen benutten binnen vergunningverlening, scenarioberekeningen, afstemming en aanpassing regelgeving rijksoverheid.

- Praktijk: kennis verzamelen en delen over emissiereducties van technieken en stalsystemen, innovaties bevorderen en faciliteren, meetmethodes en -strategieën testen en verbeteren.

Binnen de 'praktijk-route' is het Praktijkcentrum Emissiereductie Veehouderij (PEV) opgericht waarmee de betrokkenen van het Manifest GLV versneld willen werken aan het ontwikkelen en praktijkrijp brengen van haalbare en betaalbare emissie reducerende technieken en stalsystemen die nog niet beschikbaar zijn in de Lijst Emissiefactoren fijn stof voor veehouderij (Rijksoverheid, 2018).

Hoewel het PEV zich wil richten op het verminderen van emissies van alle vormen van luchtverontreiniging uit stallen, is er in eerste instantie gekozen om de aandacht te richten op technieken die de emissie van fijnstof reduceren. Hiertoe is een traject opgestart waarbij innoverende leveranciers van technieken hun systeem aan konden melden met daarbij relevante informatie over o.a. het werkingsprincipe, het verwachte reductiepercentage en de jaarkosten voor veehouders. Via een selectieprocedure zijn acht technieken geselecteerd die op veehouderijbedrijven zijn geïnstalleerd om het effect daarvan op de emissie van $\mathrm{PM}_{10}$ vast te stellen. In dit rapport wordt van één van deze technieken het resultaat van de metingen gepresenteerd.

\subsection{Afbakening en doelstelling}

Dit meetrapport bevat de resultaten van de emissiemetingen gedaan in de pilot met de absoluutfilters van de firma's Inno ${ }^{+}$Plettenburg, geïnstalleerd in een leghennenstal. Emissie reducerende technieken voor stallen worden normaliter getest volgens het meetprotocol zoals die is opgesteld in Nederland (Ogink et al., 2011) en in het internationale VERA collectief (VERA, 2018a). In de pilots is op een aantal punten afgeweken van deze protocollen om met beperkte inspanningen en kosten toch een goede eerste indruk te krijgen van het reductiepotentieel van een techniek. De onzekerheden die de omissies t.a.v. de protocollen met zich meebrengen worden in de discussie van dit rapport beoordeeld. Op basis van dit meetrapport kan de techniek worden opgenomen in nationale of regionale regelgeving met een (voorlopig) reductiepercentage voor fijnstof. Ondernemers in de veehouderij kunnen deze techniek vervolgens aanwenden op hun bedrijf om de belasting van de omgeving met stalstof te verlagen.

\section{$1.4 \quad$ Opzet rapport}

Zoals gebruikelijk in een meetrapport wordt in hoofdstuk 2 ingegaan op de toegepaste materialen en methoden. Daarbij wordt eerst de techniek waar de metingen zich op richtten beschreven, samen met het werkingsprincipe. Daarna volgt een korte beschrijving van de stal waarin de techniek is toegepast. Tot slot worden de gebruikte meetmethoden en de meetstrategie beschreven en de verwerking van de meetgegevens. In hoofdstuk 3 worden de resultaten van de metingen gepresenteerd, waarna in hoofdstuk 4 een discussie volgt over de aspecten die mogelijk van invloed zijn geweest op de techniek en over in hoeverre de resultaten gebruikt kunnen worden voor opname in de (nationale) regelgeving. De conclusie naar aanleiding van de discussie volgt daarna in hoofdstuk 5. 


\section{Materiaal en methoden}

\subsection{Beschrijving techniek en werkingsprincipe}

Het absoluutfilter bestaat uit een ronde koker met daaromheen een filter waardoor de ventilatielucht naar binnen wordt gezogen. Het stof blijft hierbij op en in (de buitenkant van) het filter zitten. De lucht wordt door de filters heen gehaald met behulp van een drukkamer. De onderdruk in de drukkamer kan bij maximale ventilatie oplopen tot $80 \mathrm{~Pa}$. Elk filter kan tussen de 20.000 en 25.000 $\mathrm{m}^{3} / \mathrm{h}$ aan ventilatielucht filteren. Het filter wordt vier tot 12 keer per dag gereinigd met behulp van een persluchtsysteem in de filters. Het persluchtsysteem blaast het stof van binnenuit van de filters af. Door telkens de ventilatiestroom door één filter stop te zetten en dit filter te reinigen, kan de ventilatie door de andere filters worden overgenomen. Figuur 2.1-A geeft een foto van de absoluutfilters in de binnentuin. Figuur 2.1-B geeft een foto van de techniek toegepast achter de droogtunnel.

Deze techniek met filter is reeds opgenomen in de lijst "E 7 Additionele technieken voor emissiereductie van fijnstof" met $50 \%$ reductie bij gespecificeerde ventilatiedebieten voor de verschillende diercategorieën ( $E, F$ en $G$ ). Het stoffilter heeft volgens de beschrijving in deze lijst (BWL $2020.02)$ een verwijderingspercentage voor fijnstof $\left(\mathrm{PM}_{10}\right)$ van $99 \%$.

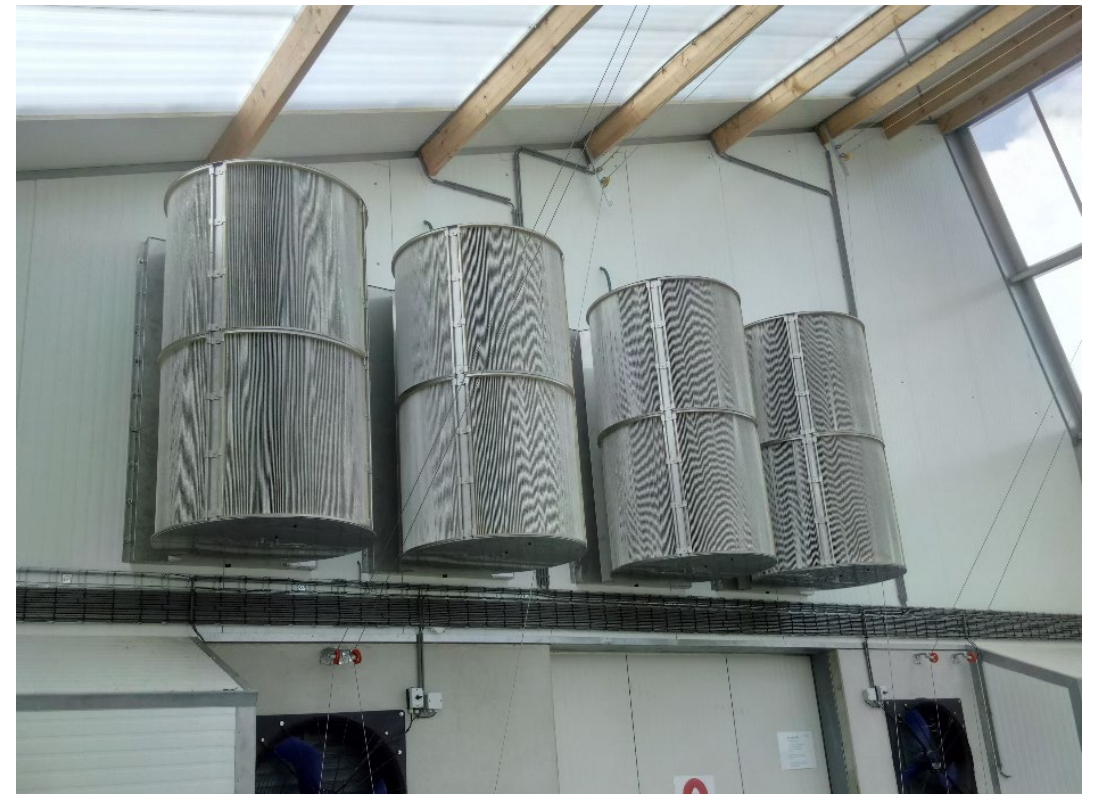

Figuur 2.1-A Foto van de absoluutfilters in de binnentuin.

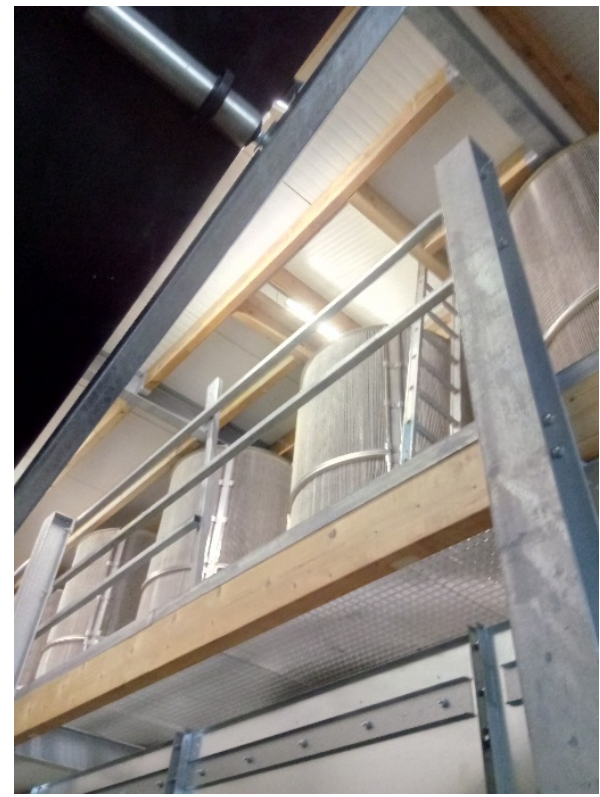

Figuur 2.1-B De absoluutfilters boven de mestdroogtunnel. 


\subsection{Beschrijving stal en bedrijfssituatie}

De metingen zijn uitgevoerd in de Kipsterstal voor leghennen. In de stal werden 24.000 leghennen gehouden, verdeeld over vier compartimenten (niet lucht gescheiden). De Kipsterstal bestaat uit twee nachtverblijven die gekoppeld zijn via een overdekte binnentuin (dagverblijf). De nachtverblijven zijn voorzien van een enkele rij volièrestellingen met legnesten, voer- en drinkwatersysteem. Aan de andere (buiten)zijde van de nachtverblijven is een vrije uitloop (zie ook plattegrond in bijlage 1). Het dak over de stal is asymmetrisch, waarbij het gedeelte over de binnentuin voorzien is van lichtdoorlatend materiaal (zie figuur 2.1-B). Aan de ene kopse kant van de stal vindt de eierverzameling plaats, aan de andere kant zitten de centrale delen voor de voer- en drinkwatervoorziening, een mestdroogtunnel en de hoofdventilatoren voor de luchtafvoer. Deze hoofdventilatoren zuigen lucht uit een drukkamer. Zowel de nachtverblijven als de binnentuin zijn voorzien van aparte ventilatoren.

Alle lucht gaat via de tien absoluutfilters naar buiten. Deze bevinden zich zowel tussen de ruimte met de droogtunnel en de drukkamer (zes stuks) als tussen de binnentuin en de drukkamer (vier stuks). De lucht wordt aangevoerd via luchtinlaatventielen in de zijgevels, of via de uitloopopeningen naar de vrije uitloop wanneer deze geopend zijn. Daarnaast is er ook beluchting op de mestbanden in de nachtverblijven aanwezig. Tot slot zijn in de binnentuin ASPRA Agro's aanwezig die zorgen voor een vermindering van de fijnstofconcentratie in de stal (voor meer informatie zie: https://www.vfasolutions.com/producten/air-cleaners/aspra-agro/).

De wanden tussen de nachtverblijven en de binnentuin kunnen volledig worden geopend (zie figuur 2.1-B en bijlage 1). De hennen krijgen van ca. 10:00 uur's ochtends tot zonsondergang toegang tot de binnentuin. Voor toegang tot de vrije uitloop aan de buitenzijden van de stal zijn uitloopopeningen aanwezig in de buitengevels. Deze zijn geopend vanaf ca. 10:15 uur's ochtends tot zonsondergang. Tijdens het uitvoeren van de metingen kregen de hennen geen toegang tot deze vrije uitloop, omdat geopende uitloopschuiven de metingen zouden verstoren.

In bijlage 1 is een overzicht opgenomen van de belangrijkste kenmerken van de stal en enkele managementaspecten, samen met enkele foto's en een overzichtsfoto van het bedrijf. Op het bedrijf zijn geen andere stallen aanwezig.

\subsection{Meetstrategie}

Emissie reducerende technieken voor stallen worden normaliter getest volgens het meetprotocol zoals die is opgesteld in Nederland (Ogink et al., 2011) en in het internationale VERA collectief (VERA, 2018a). Deze protocollen schrijven o.a. het volgende voor:

- een techniek moet op twee bedrijfslocaties worden getest om variatie in de prestatie van de techniek tussen bedrijven (t.g.v. ras, management, voeding, enzovoort) mee te nemen in het uiteindelijke reductiepercentage;

- de metingen dienen plaats te vinden in een proefstal versus een identieke referentiestal op hetzelfde bedrijf (een "case-control" strategie) of ná versus vóór een end-of-pipe-techniek zoals een filter;

- per bedrijfslocatie moeten er zes 24-uursmetingen uitgevoerd worden (totaal 12). Daarvan moeten tenminste vier metingen per bedrijfslocatie en tien in totaal betrouwbare resultaten opleveren. Door metingen over 24 uur uit te voeren wordt alle variatie die er binnen een dag optreedt meegenomen in de resultaten. De metingen moeten worden gespreid over het kalenderjaar en de productieperiode van de dieren om ook variatie t.g.v. seizoenen en productiestadia van dieren mee te nemen in de resultaten;

- de emissie bestaat uit het product van ventilatiedebiet maal concentratie van een vervuilende stof. Het protocol schrijft zowel voor het meten van het ventilatiedebiet als voor het meten van concentraties een aantal wetenschappelijk valide meetmethoden voor. Voor pluimveestallen waar meerdere ventilatoren aanwezig zijn (wat het gebruik van meetwaaiers belemmert) is de $\mathrm{CO}_{2}-$ balansmethode een valide methodiek om het ventilatiedebiet te bepalen. Voor fijnstof schrijft het Nederlandse fijnstofprotocol een gravimetrische methode voor die geschikt is voor toepassing in een stofrijke stalomgeving; 
- de bemeten stallen dienen te voldoen aan landbouwkundige randvoorwaarden (zie bijlage 2). Hierin staat opgenomen welke bedrijfsparameters tijdens het uitvoeren van de metingen dienen te worden geregistreerd en gerapporteerd, om naderhand te kunnen verifiëren of de metingen hebben plaatsgevonden onder representatieve omstandigheden.

Gezien de grote behoefte aan innovatieve technieken voor fijnstofreductie in de pluimveehouderij is in de fijnstofpilots in de Foodvalley regio beoogd om op een relatief goedkope en eenvoudige manier snel inzicht te krijgen in het perspectief en de reductie van zulke technieken. Daarom zijn er in de pilots een aantal bewuste omissies gepleegd t.a.v. de methodologie. Deze kunnen als volgt worden samengevat:

a. de gemiddelde emissiereductie is vastgesteld door een meetserie van acht metingen op één bedrijfslocatie i.p.v. twee meetseries van in totaal twaalf metingen op twee bedrijfslocaties zoals het meetprotocol dit voorschrijft;

b. het ventilatiedebiet is vastgesteld aan de hand van de $\mathrm{CO}_{2}$-balansmethode op grond van metingen van $\mathrm{CO}_{2}$ in de stal (conform het meetprotocol) maar met een vaste (niet gemeten) achtergrondwaarde voor $\mathrm{CO}_{2}$ in de buitenlucht.

Er zijn in totaal acht metingen uitgevoerd, die allen bruikbare resultaten opleverden. Metingen zijn uitgevoerd gedurende ca. 24 uur. Gedurende de onderzoeksperiode heeft de reducerende techniek in de stal de volledige onderzoeksperiode normaal gewerkt. De metingen zijn gelijktijdig uitgevoerd met metingen aan een andere techniek aanwezig in deze stal. Vandaar dat tijdens elke meting twee achtereenvolgende dagen zijn gekozen. Tussen deze dagen zijn de filters en cyclonen vervangen (zie paragraaf 2.4.1).

Tijdens voornoemde meetdagen zijn de concentraties van fijnstof $\left(\mathrm{PM}_{10}\right)$ en koolstofdioxide $\left(\mathrm{CO}_{2}\right)$ gemeten, alsook de temperatuur en relatieve luchtvochtigheid (RV). Met behulp van gasdetectiebuisjes (Kitagawa) is op iedere meetdag indicatief de ammoniakconcentratie gemeten. Er zijn geen concentraties van fijnstof, dan wel waarden van temperatuur en RV gemeten in de buitenlucht. Voor deze waarden is gebruik gemaakt van de dichtstbijzijnde meetstations van het KNMI (voor temperatuur en RV) en het RIVM (voor $\mathrm{PM}_{10}$ ) voor dezelfde periode als de meetperioden. Voor de concentratie van $\mathrm{CO}_{2}$ in de buitenlucht is een vaste waarde van 400 ppm gebruikt. De emissie is gebaseerd op $\mathrm{CO}_{2}$-concentraties van metingen in de voorruimte van de droogtunnel. In deze ruimte komt zowel de lucht uit de binnentuin als uit de nachthokken.

Voor het bepalen van het verschil in de concentraties na de droogtunnel en in de drukkamer is een positie gekozen zodanig dat de luchtsnelheid beneden $2 \mathrm{~m} / \mathrm{s}$ bleef om niet-isokinetische condities (d.w.z. condities waarbij de luchtsnelheid in de stal en die van de sample flow te zeer uit de pas lopen en grotere deeltjes onder- of overbemonsterd worden) te voorkomen. Figuur 2.2-A geeft de situatie in de bemeten stal weer van de meetpositie in de drukkamer (ventilatielucht na de filters) en figuur 2.2B geeft de situatie aan achter de droogtunnel (ventilatielucht voor de filters). In de plattegrond in bijlage 1 zijn de meetpunten met een blauwe cirkel aangegeven. 


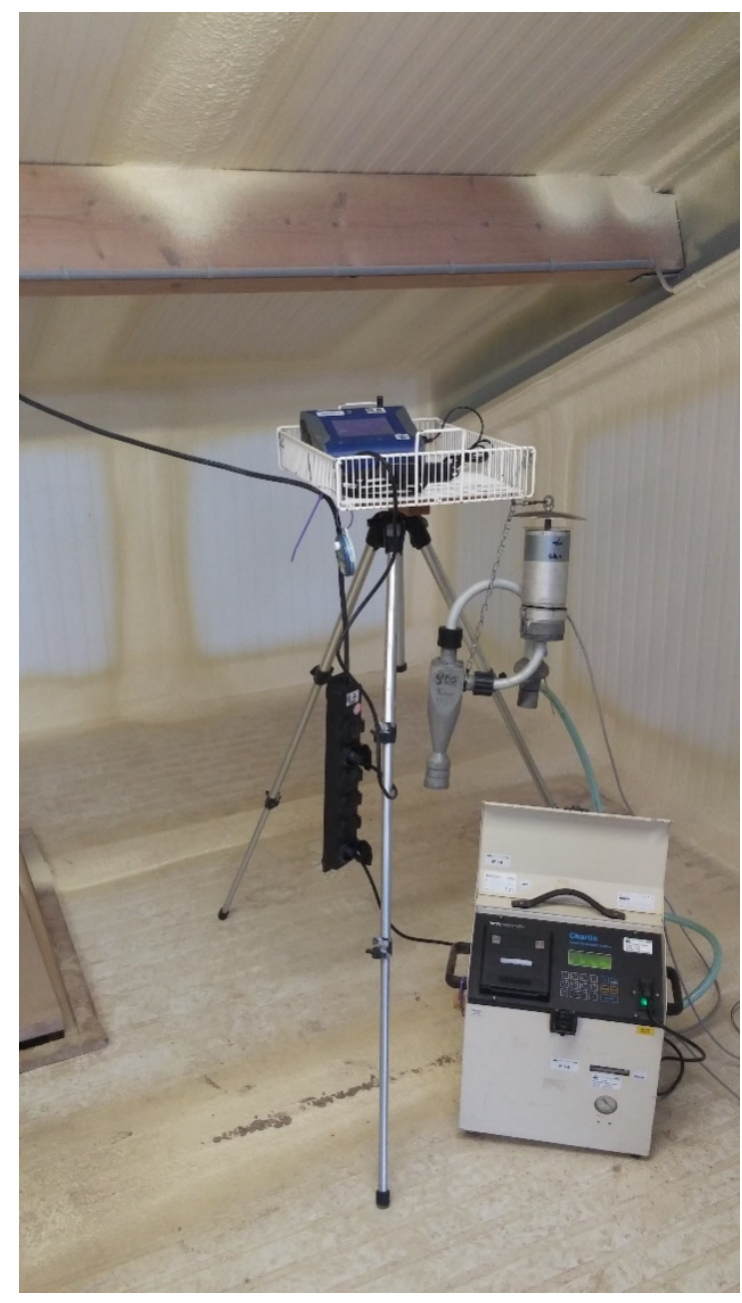

Figuur 2.2-A Plaats van de meting van de concentraties in de drukkamer.

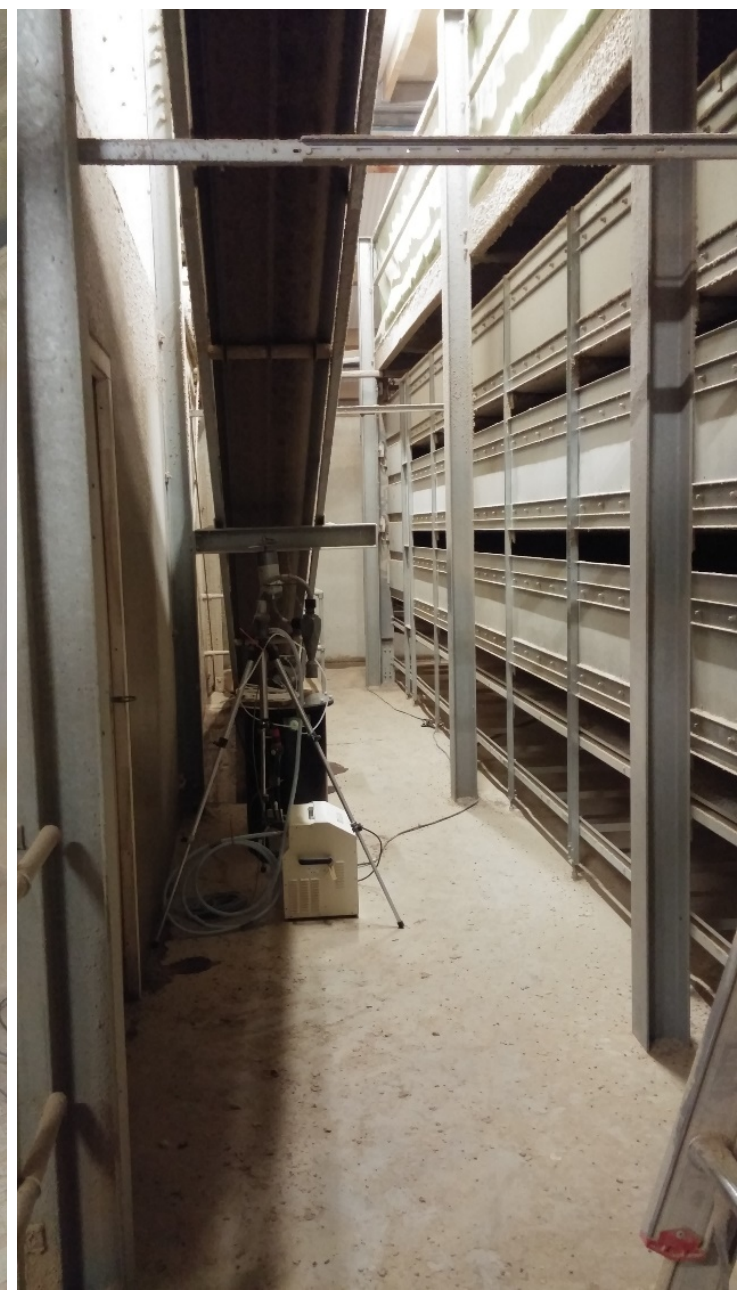

Figuur 2.2-B Plaats van de meting van de concentraties achter de droogtunnel.

\section{$2.4 \quad$ Meetmethoden}

\subsubsection{Fijnstof $\left(\mathrm{PM}_{10}\right)$}

De concentratie van $\mathrm{PM}_{10}$ in de stallucht is gemeten volgens de gravimetrische meetmethode. $\mathrm{PM}_{10}$ wordt verzameld op een filter, nadat de grotere stofdeeltjes zijn afgescheiden met behulp van een $\mathrm{PM}_{10}$-cycloon (URG corp., Chapel Hill, VS). Het stof wordt verzameld op glasvezelfilters met een diameter van 47 mm (type MN GF-3, Macherey-Nagel GmbH \& Co., Düren, Duitsland). De filters worden voor en na de stofmonstername van 24 uur gewogen onder standaard condities: temperatuur $20^{\circ} \mathrm{C} \pm 1^{\circ} \mathrm{C}$ en $50 \% \pm 5 \%$ relatieve luchtvochtigheid. Deze voorwaarden staan beschreven in NEN-EN 14907 (2005). Het verschil in gewicht voor en na de metingen wordt gebruikt om de hoeveelheid verzameld stof te bepalen. Lucht wordt door inlaat, cycloon en filter gezogen met monsternamepompen van het type Charlie HV (roterend, $6 \mathrm{~m}^{3} / \mathrm{uur}$, Ravebo Supply BV, Brielle). Deze 'constant flow' pompen regelen het debiet automatisch op basis van de gemeten temperatuur bij de monsternamekop (inlaat). Het debiet van deze pompen blijft ook constant bij toename van de drukval over het filter. Hierdoor wordt een stabiele luchtstroom verkregen binnen $2 \%$ van de nominale waarde. De pompen worden geprogrammeerd op een flow van 1,0 $\mathrm{m}^{3} / \mathrm{uur}$ en op een start- en eindtijd van de monsternameperiode. De werkelijke hoeveelheid lucht die bij de monsternamepunten wordt aangezogen wordt met een gasmeter gemeten (gecorrigeerd naar de temperatuur bij de monsternamepunten). 


\subsubsection{Ventilatiedebiet}

Ten behoeve van het vaststellen van het ventilatiedebiet is de concentratie van koolstofdioxide $\left(\mathrm{CO}_{2}\right)$ gemeten. Via de $\mathrm{CO}_{2}$-balansmethode is het ventilatiedebiet bepaald.

De $\mathrm{CO}_{2}$-concentratie is gemeten met de zgn. 'longmethode'. In deze methode (Ogink en Mol, 2002) wordt eerst een 40 liter Nalophan monsterzak in een gesloten vat geplaatst. Door lucht uit het vat met behulp van een pomp (Thomas Industries Inc., model 607CD32, Wabasha, Minnesota, VS) via een teflon slang te zuigen, ontstaat in het vat onderdruk en wordt de te bemonsteren lucht aangezogen in de zak. Bij de bepaling van de $\mathrm{CO}_{2}$-concentratie wordt de monsterzak gedurende 24 uur continu gevuld met een vaste luchtstroom van $0,02 \mathrm{l} / \mathrm{min}$. Het gehalte aan $\mathrm{CO}_{2}$ in het monster wordt bepaald met een gaschromatograaf (Interscience/Carbo Erba Instruments, GC 8000 Top; kolom: Molsieve 5A $\left(\mathrm{CH}_{4}, \mathrm{CO}_{2}\right)$, Haysep Q $\left(\mathrm{N}_{2} \mathrm{O}\right)$; detector: HWD).

Om inzicht te krijgen in het verloop van de $\mathrm{CO}_{2}$-concentratie over 24 uur vanwege de afwezigheid van de dieren gedurende bepaalde perioden, zijn ook enkele metingen uitgevoerd met een elektronische sensor. Hierbij is gebruik gemaakt van een Vaisala $\mathrm{CO}_{2}$-sensor (Vaisala; Vantaa, Finland; CARBOCAP ${ }^{\circledR}$ Carbon Dioxide Probe GMP252; type met meetbereik 0-5000 ppm).

\subsubsection{Temperatuur en relatieve luchtvochtigheid}

Ter vastlegging van de meetomstandigheden werden temperatuur en relatieve luchtvochtigheid gemeten met een gecombineerde logger (Escort iLog; Askey dataloggers; Leiderdorp, Nederland).

\subsubsection{Productiegegevens}

Op iedere tweede dag van de metingen is de volgende informatie overgenomen van de hokkaart:

- aantal opgezette en aanwezige dieren;

- indien mogelijk: gemiddeld diergewicht (eventueel afgelezen waarde voor het betreffende productiestadium uit de productiegids van het merk dier);

- voerverbruik van de dieren;

- waterverbruik van de dieren;

- legpercentage;

- eigewicht;

- uitval;

- eventuele toediening van medicatie of additieven.

\subsection{Dataverwerking en analyse}

\subsubsection{Berekening ventilatiedebiet}

Voor het berekenen van het ventilatiedebiet per afzonderlijke meetdag is de $\mathrm{CO}_{2}$-balansmethode gebruikt. Deze methode is gebaseerd op de rekenregels van de CIGR voor het bepalen van de $\mathrm{CO}_{2}-$ productie van de dieren (CIGR, 2002; Pedersen et al., 2008). Hiervoor wordt eerst de warmteproductie van de leghennen als volgt berekend:

$$
\Phi_{\text {tot }}=6,8 m^{0,75}+25 Y_{2}
$$

waarbij:

- $\Phi_{\text {tot }}=$ totale warmteproductie per dier in $\mathrm{W}$;

- $\mathrm{m}$ = gewicht van het dier in $\mathrm{kg}$

- $\mathrm{Y}_{2}=$ eiproductie in $\mathrm{kg} / \mathrm{dag}$.

De $\mathrm{CO}_{2}$-productie werd vervolgens berekend met behulp van de volgende formule:

$$
\mathrm{CO}_{2}-\text { productie }=\Phi_{\text {tot }} * 0,185
$$

waarbij:

- $\mathrm{CO}_{2}$-productie $=$ productie van $\mathrm{CO}_{2}$ in $\mathrm{m}^{3} /$ uur per dier; 
- 0,185 = waarde voor $\mathrm{CO}_{2}$-productie per $\mathrm{kW}$ in $\mathrm{m}^{3} / \mathrm{uur}$ per dier.

Het ventilatiedebiet werd vervolgens berekend op basis van de volgende formule:

$$
\mathrm{Q}=\frac{\mathrm{CO}_{2}-\text { productie }}{\left(\left[\mathrm{CO}_{2}\right]_{\text {stal }}-\left[\mathrm{CO}_{2}\right]_{\text {buiten }}\right) * 10^{-6}}
$$

waarbij:

- $\mathrm{Q}=$ ventilatiedebiet in $\mathrm{m}^{3} /$ uur per dier;

- $\left[\mathrm{CO}_{2}\right]_{\text {stal }}=\mathrm{CO}_{2}$ concentratie in parts per million $(\mathrm{ppm})$ gemeten bij het emissiepunt van de stal;

- $\left[\mathrm{CO}_{2}\right]_{\text {buiten }}=$ vaste waarde voor de concentratie van $\mathrm{CO}_{2}$ van $400 \mathrm{ppm}$.

\subsubsection{Berekening fijnstofemissie}

Per afzonderlijke meetdag werd de emissie van PM10 bepaald, d.w.z. zowel voor de 'referentiedagen' als de 'proefdagen' binnen de proefstal, op basis van de volgende formule:

$$
E=Q *\left(\left[P M_{10}\right]_{\text {stal }}-\left[P M_{10}\right]_{\text {buiten }}\right) * 10^{-6} * 24 * 365
$$

waarbij:

- $\mathrm{E}=$ emissie van $\mathrm{PM}_{10}$ in $\mathrm{g} / \mathrm{jaar}$ per aanwezig dier;

- $\mathrm{Q}=$ ventilatiedebiet in $\mathrm{m}^{3} / \mathrm{uur}$ per dier;

- $\left[\mathrm{PM}_{10}\right]_{\text {stal }}=$ de concentratie van $\mathrm{PM}_{10}$ in $\mu \mathrm{g} / \mathrm{m}^{3}$, gemeten nabij het emissiepunt van de stal;

- $\left[\mathrm{PM}_{10}\right]_{\text {buiten }}=$ de concentratie van $\mathrm{PM}_{10}$ in $\mu \mathrm{g} / \mathrm{m}^{3}$, gemeten door het dichtstbijzijnde meetstation van het Landelijk Meetnet Luchtkwaliteit voor dezelfde periode;

- $10^{-6}=$ conversiefactor van $\mu \mathrm{g}$ naar $\mathrm{g}$;

- 24 = conversiefactor van uur naar dag;

- 365 = conversiefactor van dag naar jaar.

Er wordt in bovenstaande berekening geen rekening gehouden met de leegstand tussen productieperioden. Dit is wel nodig bij het berekenen van een absolute emissiefactor, maar niet in deze situatie voor het berekenen van een reductiepercentage.

\subsubsection{Berekening eindreductiepercentage fijnstofemissie met bandbreedte}

In de pilot was sprake van de volgende situatie:

- leghennen met een stabiel emissiepatroon;

- meetdagen die gebalanceerd zijn gekozen over de productieperiode en het jaar.

In deze situatie is het eindreductiepercentage berekend over de emissies. Door eerst de emissies voor en na het filter te middelen en vervolgens een eindreductiepercentage te berekenen over die twee gemiddelde emissiecijfers worden de individuele reductiepercentages gewogen naar rato van hun bijdrage aan de totale emissie.

Om enig inzicht te krijgen in de precisie waarmee het verkregen eindreductiepercentage is bepaald, zijn voor dit cijfer een aantal betrouwbaarheidsintervallen berekend. Een $\mathrm{x} \%$-betrouwbaarheidsinterval is een combinatie van een ondergrens en bovengrens waarvoor het voor $x \%$ zeker is dat het gemiddelde daarin valt. Hiervoor zijn de reductiepercentages van de individuele metingen gebruikt. Onder de aanname van statistische onafhankelijkheid en normaliteit geldt dat het betrouwbaarheidsinterval gelijk is aan het gemiddelde $\pm t_{(v=n-1 ; \alpha)} * \mathrm{SE}$, waarbij $t$ de waarde is uit de Student-verdeling bij $v$ vrijheidsgraden, $n$ waarnemingen en een onbetrouwbaarheidsdrempel $\alpha$ en SE de standaardfout (berekend als de standaardafwijking gedeeld door de wortel uit het aantal waarnemingen). 


\subsubsection{Statistische analyses}

Relaties tussen het reductiepercentage en mogelijke invloedsfactoren (fijnstofconcentratie, ventilatiedebiet) op de effectiviteit van de techniek werden verkend met behulp van Enkelvoudige Lineaire Regressie. Hier is een effect van de invloedsfactor ( $\mathrm{X}$-variabele) op het reductiepercentage ( $\mathrm{Y}$ variabele) verkend door te toetsen of de richtingscoëfficiënt significant afwijkt van nul.

Doordat telkens twee dagen achter elkaar is gemeten zijn deze waarnemingen niet onafhankelijk. Daarom zijn de achtereenvolgende dagen gemiddeld. Dit is gedaan om conservatief te toetsen. Vervolgens zijn de paartjes (voor en na het filter) van waarnemingen als statistisch onafhankelijk beschouwd. Verschillen of relaties werden als statistisch significant beschouwd bij een P-waarde $<0,05$ en als trendmatig bij een P-waarde tussen 0,05 en 0,10. Alle analyses werden uitgevoerd met behulp van het statistische programma GenStat (VSN, 2019). 


\section{Resultaten}

\subsection{Meetomstandigheden}

Het Nederlandse meetprotocol voor fijnstof (Ogink et al., 2011) schrijft voor dat er per bedrijfslocatie zesmaal gemeten moet worden. De metingen moeten gelijkmatig verdeeld over een jaar zijn verricht. Figuur 3.1 laat zien hoe de metingen op de locatie in werkelijkheid verdeeld waren. Minimaal $80 \%$ van de metingen moet betrouwbare resultaten opleveren. De metingen moeten gebalanceerd over de productieperiode zijn uitgevoerd.
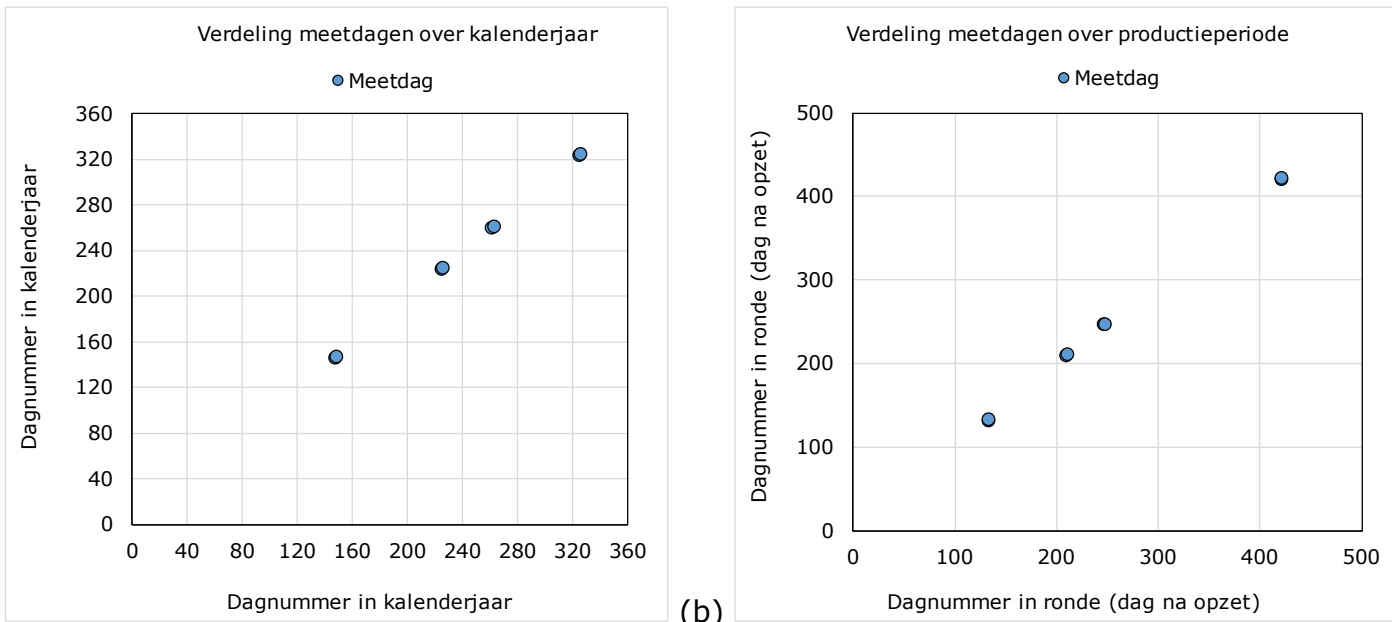

(a)

(b)
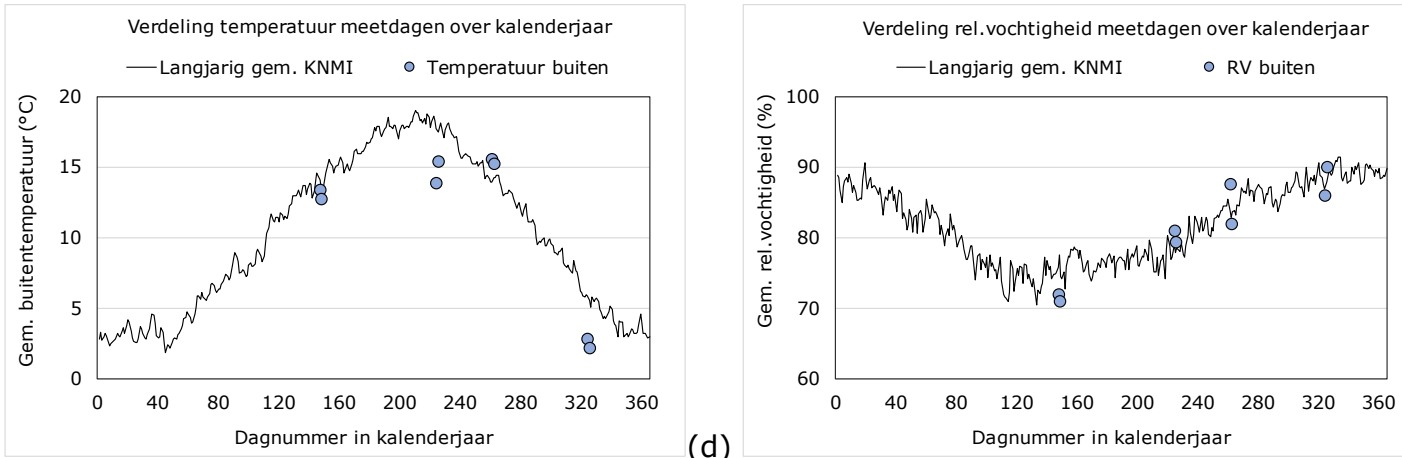

Figuur 3.1 Verdeling van de metingen over het jaar (a), en productieperiode (b) en in vergelijking met de buitentemperatuur (c) en relatieve luchtvochtigheid (d) volgens de gemiddelde waarden gemeten over 1981 t/m 2010 van het KNMI-station De Bilt (weergegeven als lijn).

Er zijn in totaal acht metingen uitgevoerd in de periode november 2018 tot en met september 2019. Hiervan gaven alle acht metingen betrouwbare resultaten. De metingen zijn telkens op twee achtereenvolgende dagen uitgevoerd, hierdoor zijn in figuur 3.1a en 3.1b maar vier punten te zien.

Het gemiddelde dagnummer van de dagen waarop is gemeten is 240 (streven: ca 183). De metingen zijn niet geheel gelijkmatig over het jaar verdeeld. Er zijn vooral metingen gedaan in de tweede helft van het jaar. Door omstandigheden (afwezigheid meettechnici door ziekte, leegstand en aanpassingen aan stal en systeem) zijn nagenoeg alle metingen uitgevoerd in het tweede deel van het jaar. Dezelfde omstandigheden hebben ook geleid tot een ongelijke verdeling van de metingen over de productieperiode. Hierbij mist een meting in de eerste weken na opzet van de dieren.

In tabel 1 zijn o.a. de data waarop de metingen zijn uitgevoerd met de relevante technische resultaten en klimaatomstandigheden (buiten en binnen in de stal) weergegeven. De technische resultaten van de dieren (wateropname, voeropname, water/voer-verhouding, productie, en uitval) vielen nagenoeg 
allemaal binnen de normen van het ras die gesteld zijn door de fokkerijgroepering en de landbouwkundige voorwaarden (zie bijlage 2). Tijdens één meetdag lag de gemiddelde $\mathrm{CO}_{2}-$ concentratie, gemeten in de ruimte voor de droogtunnel, boven de $3.000 \mathrm{ppm}$. In deze ruimte bevinden zich geen dieren. Daarmee weten we niet of de concentratie in de dierruimten ook boven de 3.000 ppm is geweest. Op de laatste meetdag lag het uitvalspercentage net boven de $8 \%$, dit percentage is opgelopen tot meer dan $10 \%$. Het relatief al hoge uitvalspercentage tijdens de laatste meetdag (het dubbele van de eerste productieronde op dezelfde leeftijd) is veroorzaakt door de hoge buitentemperaturen in de zomer van 2019.

De gemiddelde buitentemperatuur bedroeg $11,4^{\circ} \mathrm{C}$ voor de meetdagen (langjarig gemiddelde KNMI: $10,2^{\circ} \mathrm{C}$ ). Voor de RV was dit 81\% (langjarig gemiddelde KNMI: 82\%). De gemiddelde buitentemperatuur tijdens de metingen lag daarmee $1,2^{\circ} \mathrm{C}$ hoger dan het langjarig gemiddelde. Dit komt voornamelijk door het grotere aantal metingen in de zomerperiode. De gemiddelde RV tijdens de meetdagen lag slechts $1 \%$ onder het langjarig gemiddelde.

De gemiddelde temperatuur in de stal bedroeg $22,1^{\circ} \mathrm{C}$ en de gemiddelde relatieve luchtvochtigheid in de stal bedroeg $62 \%$.

De waarden van de indicatieve ammoniakmetingen zijn niet opgenomen in tabel 1 . Ze varieerden binnen de normale waarden voor stallen met leghennen en geven geen aanleiding om een relatie met de absoluutfilters te analyseren.

Tabel 1 Data warop de metingen zijn uitgevoerd met dagnummer in het jaar en dagnummer in productiecyclus, relevante technische resultaten en de klimaatomstandigheden (buitenklimaat en in de stal).

\begin{tabular}{|c|c|c|c|c|c|c|c|c|}
\hline \multirow{3}{*}{\begin{tabular}{|l|} 
Variabele ([eenheid] \\
Algemeen
\end{tabular}} & & & \multicolumn{2}{|c|}{ Meting 3} & \multicolumn{2}{|c|}{ Meting 4} \\
\hline & \multicolumn{2}{|c|}{$\begin{array}{l}\text { Meting } 1 \\
\text { Dag } 1\end{array}$} & \multicolumn{2}{|c|}{ Dag $1 \quad$ Dag 2} & \multicolumn{2}{|c|}{ Dag $1 \quad$ Dag 2} & \multicolumn{2}{|c|}{ Dag 1 Dag 2} \\
\hline & & & & & & & & \\
\hline Datum start meting [dd-mm-yyyy] & $20 / 11 / 2018$ & $21 / 11 / 2018$ & $27 / 05 / 2019$ & $28 / 05 / 2019$ & $12 / 08 / 2019$ & $13 / 08 / 2019$ & $18 / 09 / 2019$ & $19 / 09 / 2019$ \\
\hline Tijd start meting [hh:mm] & $11: 50$ & $12: 45$ & $9: 45$ & $10: 45$ & $12: 30$ & $12: 30$ & $9: 00$ & $10: 00$ \\
\hline Datum einde meting [dd-mm-yyyy] & $21 / 11 / 18$ & $22 / 11 / 18$ & 28/05/19 & $29 / 05 / 19$ & $12 / 08 / 19$ & $13 / 08 / 19$ & $19 / 09 / 19$ & $20 / 09 / 19$ \\
\hline Tijd einde meting [hh:mm] & $11: 50$ & $12: 45$ & $9: 45$ & $10: 45$ & $11: 50$ & $12: 45$ & $9: 00$ & $10: 00$ \\
\hline Dagnummer in jaar [\#] & 324 & 325 & 147 & 148 & 224 & 225 & 261 & 262 \\
\hline \multicolumn{9}{|l|}{ Productiekengetallen } \\
\hline Opzetdatum dieren [dd-mm-yyyy] & \multicolumn{2}{|c|}{$26 / 09 / 17$} & \multicolumn{2}{|c|}{$15 / 01 / 19$} & \multicolumn{2}{|c|}{$15 / 01 / 19$} & \multicolumn{2}{|c|}{$15 / 01 / 19$} \\
\hline Ras & \multicolumn{2}{|c|}{ DEKALB White } & \multicolumn{2}{|c|}{ DEKALB White } & \multicolumn{2}{|c|}{ DEKALB White } & \multicolumn{2}{|c|}{ DEKALB White } \\
\hline Dagnummer in productieronde & 420 & 421 & 132 & 133 & 209 & 210 & 246 & 247 \\
\hline Aantal dieren geplaatst & \multicolumn{2}{|c|}{23976} & \multicolumn{2}{|c|}{24000} & \multicolumn{2}{|c|}{24000} & \multicolumn{2}{|c|}{24000} \\
\hline Aantal dieren aanwezig & 22730 & 22721 & 23571 & 23565 & 23262 & 23260 & 23101 & 23096 \\
\hline Uitval cumulatief [\%] & 5.2 & 5.2 & 1.8 & 1.8 & 3.1 & 3.1 & 3.7 & 3.8 \\
\hline Diergewicht [g] & 1693 & 1705 & 1720 & 1720 & 1729 & 1729 & 1718 & 1718 \\
\hline Voeropname [ $\mathrm{g} /$ dier per dag] & 120 & 120 & 114.5 & 114.5 & 117.4 & 117.4 & 118.7 & 118.7 \\
\hline Wateropname [mL/dier per dag] & 220 & 220 & 263 & 263 & 257 & 257 & 258 & 258 \\
\hline Water/voer-verhouding & 1.8 & 1.8 & 2.3 & 2.3 & 2.2 & 2.2 & 2.2 & 2.2 \\
\hline Legpercentage & 84.3 & 84.2 & 92.1 & 92.1 & 95.1 & 95.1 & 94 & 94 \\
\hline Gemiddeld eigewicht $(\mathrm{g})$ & 59.8 & 60.1 & 55.8 & 55.8 & 58.7 & 58.7 & 59 & 59 \\
\hline \multicolumn{9}{|l|}{ Buitenluchtcondities } \\
\hline Gem. temperatuur (KNMI) $\left[{ }^{\circ} \mathrm{C}\right]$ & 2.8 & 2.2 & 13.4 & 12.7 & 13.9 & 15.4 & 15.6 & 15.2 \\
\hline Gem. Relat. luchtvochtigheid (KNMI) [\%] & 86 & 90 & 72 & 71 & 81 & 79 & 88 & 82 \\
\hline Achtergrond PM10 (LML) $\left[\mu \mathrm{g} / \mathrm{m}^{3}\right]$ & 32.3 & 35.5 & 10.6 & 9.6 & 11.0 & 8.6 & 11.7 & 9.4 \\
\hline Achtergrond PM2.5 (LML) $\left[\mu \mathrm{g} / \mathrm{m}^{3}\right]$ & 26.6 & 27.0 & 6.3 & 8.3 & 6.7 & 6.7 & 5.4 & 4.9 \\
\hline \multicolumn{9}{|l|}{ Stallucht en ventilatie } \\
\hline Luchttemperatuur $\left[{ }^{\circ} \mathrm{C}\right]$ & 15.4 & 16.4 & 28.1 & 24.9 & 18 & 25.8 & 24.4 & 23.9 \\
\hline Relatieve luchtvochtigheid [\%] & 73 & 73 & 56 & 63 & 56 & 60 & 58.7 & 58.8 \\
\hline $\mathrm{CO}_{2}$-concentratie voor droogtunnel $[\mathrm{ppm}]$ & 3046 & 2950 & 2151 & 2188 & 1540 & 1621 & 2112 & 2278 \\
\hline Ventilatiedebiet $\left[\mathrm{m}^{3} / \mathrm{h}\right.$ per $\left.\operatorname{dier}\right]$ & 0.79 & 0.83 & 1.21 & 1.19 & 1.89 & 1.76 & 1.25 & 1.14 \\
\hline \multicolumn{9}{|l|}{ Fijnstofconcentraties en -emissies } \\
\hline Concentratie PM10 voor filter $\left[\mu \mathrm{g} / \mathrm{m}^{3}\right]$ & 2566 & 1653 & 4469 & 2699 & 1396 & 1835 & 2290 & 2227 \\
\hline Concentratie PM10 na filter $[\mu \mathrm{g} / \mathrm{m} 3]$ & 170 & 160 & 100 & 1277 & 791 & 566 & 480 & 613 \\
\hline Concentratiereductie PM10 abs. $\left[\mu \mathrm{g} / \mathrm{m}^{3}\right]$ & 2397 & 1493 & 4370 & 1422 & 605 & 1269 & 1810 & 1614 \\
\hline Concentratiereductie PM10 rel. [\%] & 93.4 & 90.3 & 97.8 & 52.7 & 43.3 & 69.2 & 79.0 & 72.5 \\
\hline Gem. emissie PM10 voor filter [g/dier per jaar] & 17.6 & 11.7 & 47.4 & 28.0 & 22.9 & 28.2 & 25.0 & 22.2 \\
\hline Gem. emissie PM10 na filter [g/dier per jaar] & 1.0 & 0.9 & 0.9 & 13.2 & 12.9 & 8.6 & 5.1 & 6.0 \\
\hline Emissiereductie PM10 abs. [g/dier per jaar] & 17 & 11 & 47 & 15 & 10 & 20 & 20 & 16 \\
\hline Emissiereductie PM10 rel. [\%] & 94.6 & 92.3 & 98.0 & 52.9 & 43.7 & 69.5 & 79.5 & 72.8 \\
\hline
\end{tabular}




\section{2 $\mathrm{CO}_{2}$-concentratie en ventilatiedebiet}

Tabel 1 toont de gemeten $\mathrm{CO}_{2}$-concentraties. De gemiddelde $\mathrm{CO}_{2}$-concentratie voor de droogtunnel bedroeg $2236 \mathrm{ppm}$. Op basis van de in tabel 1 weergegeven $\mathrm{CO}_{2}$-concentraties voor de ruimte voor de droogtunnel zijn de ventilatiedebieten berekend. In figuur 3.2 zijn deze weergegeven ten opzichte van het dagnummer in een kalenderjaar. Het ventilatiedebiet vertoont een relatief vlak patroon met in verhouding lage waarden. Dagen met debieten boven $2 \mathrm{~m}^{3} / \mathrm{uur}$ per dier ontbreken in de dataset. Een vergelijking met het verloop van het ventilatiedebiet met andere meetrapporten is moeilijk te maken, er zijn geen meetrapporten beschikbaar met metingen bij dezelfde dieren en huisvesting. Het gemiddelde ventilatiedebiet ( \pm standaardafwijking) bedroeg $1,3( \pm 0,4) \mathrm{m}^{3} /$ uur per dier.

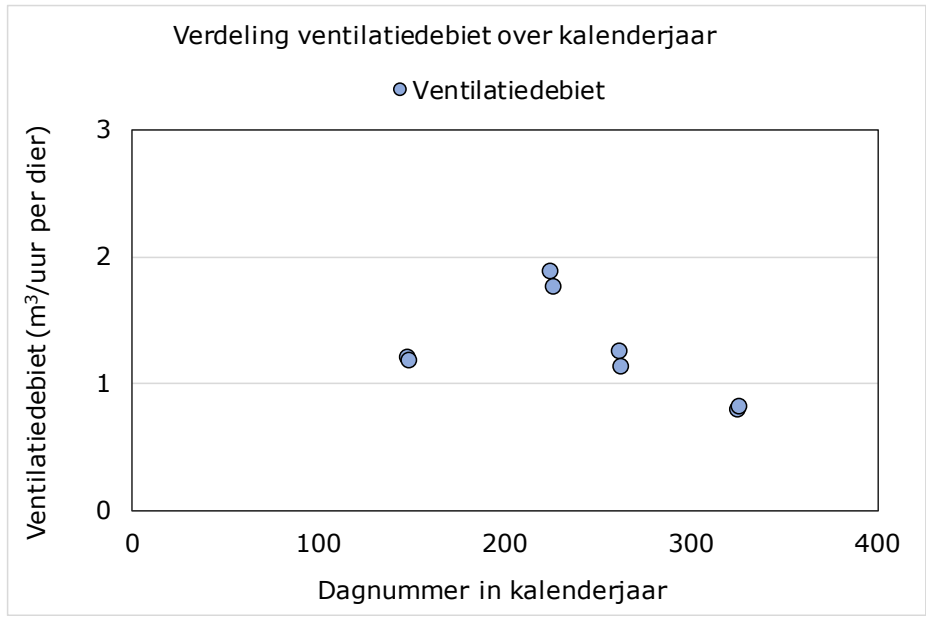

Figuur 3.2 Verdeling van het ventilatiedebiet over de kalenderjaar.

\subsection{Concentratie, emissie en reductie $\mathrm{PM}_{10}$}

De concentraties en emissies van $\mathrm{PM}_{10}$ op meetdagen voor en na de filters wordt weergegeven in figuur 3.4. In de figuur is duidelijk te zien dat zowel de concentraties als de emissies na het filter lager waren dan voor het filter.
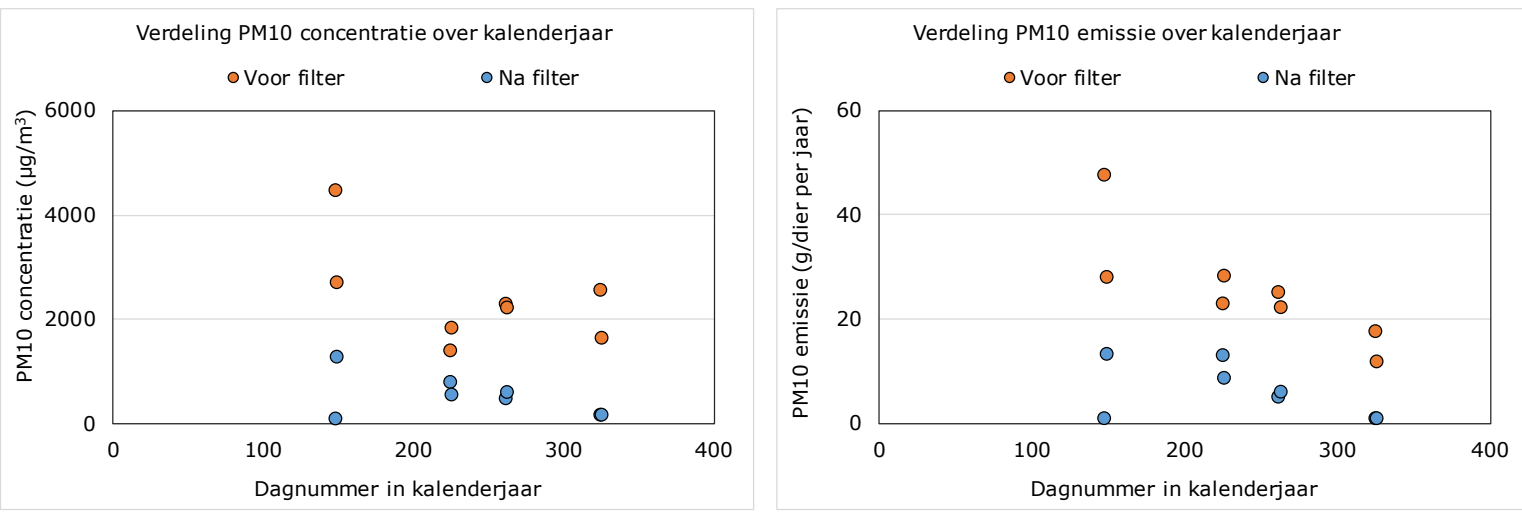

Figuur 3.4 PM10 concentraties (links) en PM10 emissies (rechts) voor en na het absoluutfilter.

De gemiddelde ( \pm standaardafwijking) $\mathrm{PM}_{10}$ concentratie voor het filter bedroeg $2392( \pm 841) \mu \mathrm{g} / \mathrm{m}^{3}$, versus $520( \pm 245) \mu \mathrm{g} / \mathrm{m}^{3}$ achter het filter. Uit de statistische analyse bleek dit verschil significant $(P=0,009)$.

De gemiddelde $\mathrm{PM}_{10}$ emissie uit de stal (berekend zoals beschreven in paragrafen 2.5 .2 en 2.5.3) bedroeg 25,4 $( \pm 9,5) \mathrm{g} /$ dier per jaar voor het filter, versus $6,1( \pm 4,1) \mathrm{g} /$ dier per jaar na het filter. Uit 
de statistische analyse bleek het verschil statistisch significant $(P=0,008)$. Op basis van deze beide waarden bedraagt het eindreductiepercentage van de techniek $76 \%$.

In figuur 3.5 worden de reductiepercentages weergegeven als functie van dagnummer in de productieronde, het ventilatiedebiet en de $\mathrm{PM}_{10}$ concentratie voor het filter. Omdat het hier slechts gaat om vier meetperioden van twee dagen (vier waarnemingen) aan één bedrijfslocatie moet deze verkenning naar invloedsfactoren op de effectiviteit van de techniek met voorzichtigheid worden geïnterpreteerd. Het algemene beeld uit figuur 3.5 is die van een reductiepercentage welke niet wordt beïnvloed gedurende de productieperiode. Het reductiepercentage lijkt te worden beïnvloed door het ventilatiedebiet: de reductie neemt af met het ventilatiedebiet. Het ventilatiedebiet heeft dan ook een bijna significante relatie met het reductiepercentage $(P=0,050)$. Deze relatie kan ook worden gezien bij enkele metingen in Winkel et al. (2011), alhoewel het absoluutfilter in dit onderzoek een ander werkingsprincipe heeft. Daarnaast lijkt het reductiepercentage toe te nemen met de $\mathrm{PM}_{10}$ concentratie voor het filter. Deze relatie is echter grotendeels toe te wijzen aan één waarneming en is niet statistisch significant $(P=0,207)$.

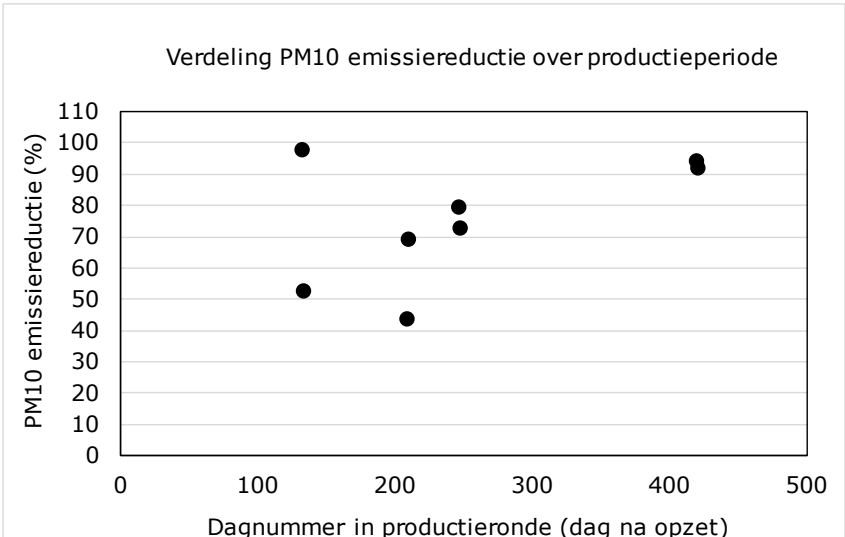

(a)

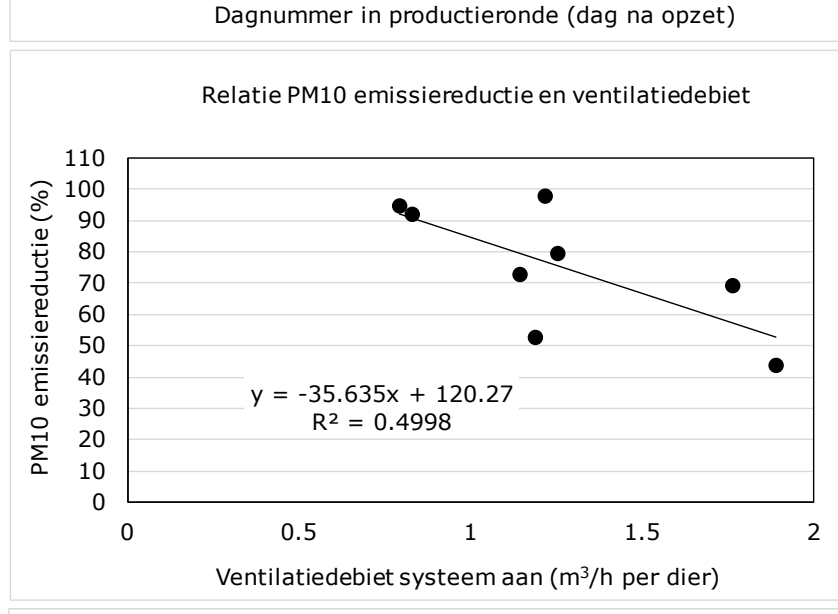

(b)

(c)

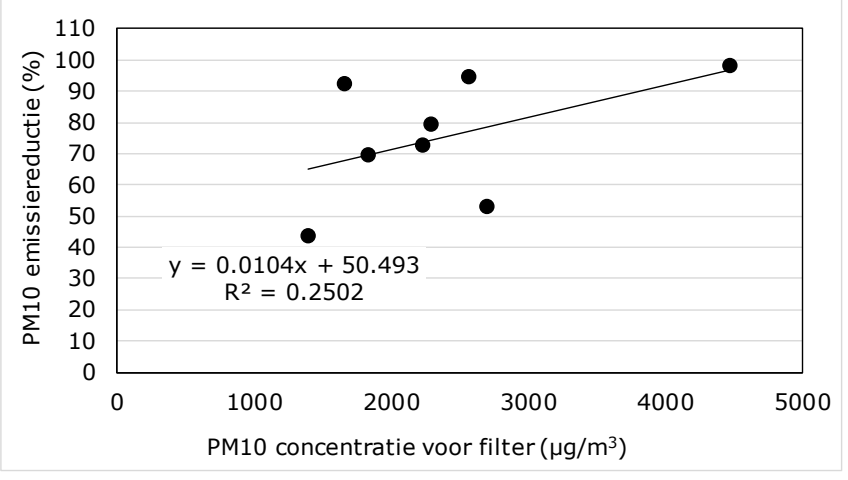

Figuur 3.5 Het reductiepercentage voor PM10 als functie van (a) dagnummer in de productieronde, (b) het ventilatiedebiet en (c) de $P M_{10}$ concentratie voor het filter. 


\section{Discussie}

Ten aanzien van de resultaten van de metingen en de vertaling ervan naar een reductiepercentage moeten de volgende discussiepunten in acht worden gehouden. De beoordeling van deze discussiepunten leiden uiteindelijk tot de conclusie verwoord in hoofdstuk 5.

Voor het toepassen van emissie reducerende technieken in stallen in het kader van het verkrijgen van een omgevingsvergunning dienen deze technieken opgenomen te zijn in de officiële "Lijst emissiefactoren fijn stof voor veehouderij" zoals die regelmatig wordt geactualiseerd en gepubliceerd op de website van de Rijksoverheid (Rijksoverheid, 2018). Opname van de techniek in de lijst met een bepaald reductiepercentage vindt plaats nadat er door de leverancier van de techniek een aanvraag met een meetrapport is ingediend bij de Rijksdienst voor Ondernemend Nederland (RVO). Hoewel niet wettelijk vastgelegd (zoals dat overigens wel het geval is bij ammoniak) is het gebruikelijk dat het meetrapport en de daarin gevolgde methoden in overeenstemming zijn met het meetprotocol "Protocol voor meting van fijnstofemissie uit huisvestingssystemen in de veehouderij 2010" zoals gepubliceerd door Ogink et al. (2011). Om aanvragen te beoordelen vraagt RVO technisch advies aan de Technische Advies Pool (TAP). Dit is een pool van deskundigen die voor diverse bedrijven en organisaties werken. Het beoordelingsproces gaat via het beoordeling-review-principe. Dit betekent dat minimaal twee deskundigen de aanvraag beoordelen. Dit om tot een volwaardig eindadvies te komen. Op basis van dit eindadvies stelt de staatssecretaris van Infrastructuur en Waterstaat het uiteindelijk reductiepercentage vast.

Gezien de grote behoefte aan innovatieve technieken voor fijnstofreductie in de pluimveehouderij is in de fijnstofpilots in de Foodvalley regio beoogd om op een relatief goedkope en eenvoudige manier snel inzicht te krijgen in het perspectief en de reductie van zulke technieken. Daarom zijn er in de pilots een aantal bewuste omissies gepleegd t.a.v. de methodologie. Deze kunnen als volgt worden samengevat:

a. de gemiddelde emissiereductie is vastgesteld door een meetserie van acht metingen op één bedrijfslocatie i.p.v. twee meetseries van in totaal twaalf metingen op twee bedrijfslocaties zoals het meetprotocol dit voorschrijft;

b. het ventilatiedebiet is vastgesteld aan de hand van de $\mathrm{CO}_{2}$-balansmethode op grond van metingen van $\mathrm{CO}_{2}$ in de stal (conform het meetprotocol) maar met een vaste (niet gemeten) achtergrondwaarde voor $\mathrm{CO}_{2}$ in de buitenlucht;

c. de achtergrondconcentraties van fijnstof $\left(\mathrm{PM}_{10}\right)$ zijn niet gemeten, hiervoor zijn achtergrondconcentraties gebruikt van het dichtstbijzijnde meetstation in Wekerom van het Luchtmeetnet (RIVM, 2019).

Voorafgaand aan de fijnstofpilots in de Foodvalley regio zijn deze omissies toegelicht en bediscussieerd met vertegenwoordigers van het Ministerie van IenW en RVO. Afgesproken is dat de meetrapporten uit de fijnstofpilots ingediend mogen worden bij RVO en zullen worden voorgelegd ter beoordeling en advisering door de TAP. Echter, daarbij is eveneens afgesproken dat in de discussie van het meetrapport een analyse en duiding zal plaatsvinden van de extra onzekerheid die de omissies in de fijnstofpilots met zich meebrengen. Op grond van die analyse en duiding, en op grond van de beoordeling en advisering door de TAP, kan er bij vaststelling van het reductiepercentage een onzekerheidsmarge worden afgetrokken van het verkregen resultaat uit een fijnstofpilot. Als een leverancier het reductiepercentage met onzekerheidsmarge wil vervangen door een definitief (d.w.z. betrouwbaarder en waarschijnlijk hoger) reductiepercentage, dan dient een meetrapport van een tweede meetserie op een tweede bedrijfslocatie te worden ingediend bij RVO. In de onderstaande tabel wordt voor een aantal betrouwbaarheidsintervallen de ondergrenzen van de reductiepercentages en de kans dat de reductie hoger is dan deze ondergrens weergegeven. Dit ten opzichte van het gemiddelde reductiepercentage van $76 \%$.

Tabel 3 Verschillende betrouwbaarheidsintervallen met de kans dat het reductiepercentage hoger is dan de ondergrens en de ondergrens van het reductiepercentage. 


\begin{tabular}{lcc} 
Betrouwbaarheidsinterval & $\begin{array}{c}\text { Ondergrens } \\
\text { reductiepercentage }\end{array}$ & $\begin{array}{c}\% \text { Kans dat reductie hoger is dan } \\
\text { ondergrens }\end{array}$ \\
\hline $95 \%$ & $59,2 \%$ & $97,5 \%$ \\
\hline $90 \%$ & $62,8 \%$ & $95 \%$ \\
\hline $80 \%$ & $66,4 \%$ & $85 \%$ \\
\hline $70 \%$ & $68,5 \%$ & $80 \%$ \\
\hline $60 \%$ & $70,0 \%$ & $75 \%$ \\
\hline $50 \%$ & $71,3 \%$ & \\
\hline
\end{tabular}

Hierna wordt ingegaan op de onzekerheid die omissies a, b en c met zich meebrengen.

a. Eén i.p.v. twee bedrijfslocaties en acht in plaats van 12 metingen

Volgens de gehanteerde meetprotocollen moet er voor het bepalen van een reductiepercentage gemeten worden op minimaal twee bedrijfslocaties om variatie in de prestatie van de techniek tussen verschillende stallen mee te nemen in het eindreductiepercentage. In dit rapport zijn de resultaten weergegeven van metingen op één bedrijfslocatie. Op deze locatie kan de techniek - om welke reden dan ook - systematisch beter of slechter hebben gepresteerd dan de werkelijke gemiddelde prestatie zoals die theoretisch verkregen zou kunnen worden door de techniek te bemeten op een zeer groot aantal locaties. Enig inzicht in de tussenbedrijfsvariatie van ionisatietechnieken kan verkregen worden uit de meetrapporten van een negatief ionisatiesysteem van de firma Inter Continental (Ysselsteyn, Nederland) beproefd op twee vleeskuikenbedrijven en een positief ionisatiesysteem van de firma ENS Clean Air (Cuijk, Nederland) beproefd in twee leghennenstallen (beide meetrapporten zijn gepubliceerd als wetenschappelijk artikel met hierin individuele reductiepercentages per locatie door Winkel et al. (2016)). T.a.v. de eerste ionisatietechniek bedroeg het gemiddelde $\mathrm{PM}_{10}$ reductiepercentage $47 \%$ met reductiepercentages per bedrijfslocatie van gemiddeld $46 \%$ voor bedrijf 1 en $49 \%$ voor bedrijf 2 . T.a.v. de tweede ionisatietechniek bedroeg het gemiddelde $\mathrm{PM}_{10}$ reductiepercentage $6 \%$ met reductiepercentages per bedrijfslocatie van gemiddeld $12 \%$ voor bedrijf 1 en $4 \%$ voor bedrijf 2 . Deze twee ionisatietechnieken laten dus een vergelijkbaar beeld (kleine tussenbedrijfsvariatie) zien in beide locaties. Voor voornoemde twee technieken geldt dat op de kleinst mogelijke schaal ( 2 bedrijfslocaties) is laten zien dat het reductiepercentage reproduceerbaar is. Dit kan voor de techniek in dit rapport vergelijkbaar gelden, maar wellicht ook niet. Daarover wordt pas meer inzicht/betrouwbaarheid verkregen door een meetserie bij een tweede bedrijfslocatie uit te voeren.

De keuze in de fijnstofpilots om metingen uit te voeren op één bedrijfslocatie brengt verder met zich mee dat het reductiepercentage van 76\% gebaseerd is op één meetserie van 8 in plaats van 12 waarnemingen. De gevonden reductie is statistisch significant afwijkend van nul. Het 95\%betrouwbaarheidsinterval (de bovengrens en ondergrens waartussen voornoemde eindreductiepercentage met 95\% zekerheid ligt) bedraagt bij de gevonden reductie \pm 17 procentpunten. Als echter een volledige dataset van 12 waarnemingen op twee locaties voorhanden zou zijn, en als de spreiding in die dataset gelijk zou blijven aan die in de huidige dataset, dan zou t.g.v. het grotere aantal waarnemingen het 95\%-betrouwbaarheidsinterval dalen tot \pm 14 procentpunten.

Voor het vaststellen van een onzekerheidsmarge kan ook gebruik worden gemaakt van andere meetseries uit het verleden. In Winkel (2020) is dit gedaan voor de reductiepercentages voor $\mathrm{PM}_{10}$ van de al in de regelgeving opgenomen technieken. Op basis van die analyse wordt een onzekerheidsmarge voorgesteld van 10 procentpunten ten opzichte van het gemeten bedrijfsgemiddelde. Daarmee is het advies voor deze techniek om een voorlopig reductiepercentage van $66 \%$ op te nemen in de landelijke regelgeving.

\section{b. Gevoeligheidsanalyse voor geen plaatselijke meting van $\mathrm{CO}_{2}$-achtergrondconcentraties} $\mathrm{Er}$ is bij deze metingen voor gekozen om geen concentraties van $\mathrm{CO}_{2}$ en $\mathrm{PM}_{10}$ in de directe nabijheid van de stal te meten. In plaats daarvan is voor $\mathrm{CO}_{2}$ gekozen voor een vaste waarde van $400 \mathrm{ppm}$ die in werkelijkheid tot enkele tientallen ppm's hoger of lager zou kunnen zijn geweest. Om het effect van een lagere of hogere $\mathrm{CO}_{2}$-achtergrond inzichtelijk te maken is het reductiepercentage nogmaals doorgerekend op basis van een zeer lage vaste achtergrond van 300 ppm én een zeer hoge vaste 
achtergrond van 500 ppm (deze achtergrondconcentraties werken door in de berekening van het ventilatiedebiet middels de $\mathrm{CO}_{2}$-balansmethode en vervolgens in de emissieberekeningen en het reductiepercentage). De aldus verkregen reductiepercentages bedroegen 76,2\% bij 300 ppm, 76,0\% bij 400 ppm en 75,8\% bij 500 ppm. Uit deze gevoeligheidsanalyse blijkt dat het reductiepercentage nauwelijks wordt beïnvloed door de gekozen vaste achtergrond voor $\mathrm{CO}_{2}$. Dit komt doordat a) het concentratieverschil tussen binnen en buiten groot is, en b) de kleine "fout" bij het berekenen van het ventilatiedebiet voor zowel de emissie voor als achter het filter wordt gemaakt. Bij lagere concentratieverschillen tussen binnen en buiten, en bij het bemeten van een absolute emissiefactor, dient overigens altijd een $\mathrm{CO}_{2}$-achtergrond te worden bepaald.

\section{c. Gevoeligheidsanalyse voor geen plaatselijke meting van PM10-achtergrondconcentraties}

$\mathrm{Er}$ is bij deze metingen voor gekozen om geen concentraties van $\mathrm{PM}_{10}$ in de directe nabijheid van de stal te meten. In plaats daarvan is voor $\mathrm{PM}_{10}$ de gemiddelde concentratie tijdens de meetdagen van het dichtstbijzijnde meetstation van het RIVM gebruikt. Om het effect van een lagere of hogere PM10achtergrond inzichtelijk te maken is het reductiepercentage nogmaals doorgerekend op basis van een verlaging of verhoging van de $\mathrm{PM}_{10}$-achtergrondconcentratie met $20 \mu \mathrm{g} / \mathrm{m}^{3}$ (deze achtergrondconcentraties werken door in de emissieberekeningen en het reductiepercentage). Ten opzichte van het gemiddelde van $76,0 \%$ neemt het reductiepercentage met $0,6 \%$ af als de buitenconcentratie $20 \mu \mathrm{g} / \mathrm{m}^{3}$ lager is, het reductiepercentage neemt met $0,7 \%$ toe als de buitenconcentratie $20 \mu \mathrm{g} / \mathrm{m}^{3}$ hoger is . Uit deze gevoeligheidsanalyse blijkt dat het reductiepercentage nauwelijks wordt beïnvloed door de $\mathrm{PM}_{10}$-achtergrondconcentratie. Dit komt doordat a) het concentratieverschil tussen binnen en buiten groot is, b) de kleine "fout" bij het berekenen van de emissie voor zowel de emissie voor als achter het filter wordt gemaakt. Bij lagere concentratieverschillen tussen binnen en buiten en bij het bemeten van een absolute emissiefactor, dient overigens altijd een $\mathrm{PM}_{10}$-achtergrond te worden bepaald.

Hierna wordt nog ingegaan op een aantal algemene discussiepunten.

\section{Verdeling metingen over jaar en productieperiode}

Uit paragraaf 3.1 blijkt dat de metingen niet helemaal evenwichtig verdeeld zijn over alle fasen van het kalenderjaar. Dit is enerzijds inherent aan een meetserie van acht geslaagde metingen. Anderzijds had de pilot te maken met incidenten in de sector, leegstand van het bedrijf door het afleveren en weer opzetten van dieren en het uitvallen van meettechnici door ziekte. Omdat de metingen niet zijn gericht op het vaststellen van een absolute emissiefactor maar op een reductiepercentage, en omdat het werkingsprincipe van filtertechnieken waarschijnlijk niet wordt beïnvloed door seizoensinvloeden, is de onzekerheid die deze omissie veroorzaakt waarschijnlijk klein.

\section{Landbouwkundige voorwaarden}

De metingen voldoen grotendeels aan de landbouwkundige voorwaarden beschreven in bijlage 2 . Zoals aangegeven in paragraaf 3.1 is op één meetdag de gemiddelde $\mathrm{CO}_{2}$-concentratie hoger geweest dan 3.000 ppm. Maar dit is gemeten in de ruimte voor de droogtunnel, hier verblijven geen kippen. Verder is het uitvalspercentage over de hele $2^{\mathrm{e}}$ productieperiode, waarin zes van de acht metingen vielen, niet beneden de $10 \%$ is gebleven. Verwacht wordt echter dat het hogere uitvalspercentage geen effect heeft op de reducerende werking van de absoluutfilters.

\section{Andere meetrapporten}

Er zijn bij deze techniek geen andere metingen uitgevoerd in dezelfde opstelling. Wel is het filtermateriaal door verschillende instituten getest. Zo heeft het Labor für Arbeits- und Umwelthygiene het filtermateriaal getest in combinatie met een warmtewisselaar aangesloten op een vleeskuikenstal. Deze warmtewisselaar in combinatie met filter gaf een reductie van minstens $98 \%$ op gravimetrisch gemeten inadembare stofdeeltjes. Daarnaast zou 98,3\% van de endotoxinen worden afgevangen door deze warmtewisselaar met absoluutfilter (Missel, 2017). Ook een meetrapport van LUFA Nord-West aan dezelfde warmtewisselaar geeft een reductie van meer dan 98\% op PM 10 (Stevens, 2014).

Leklucht

Andere meetrapporten geven hogere reductiepercentages dan berekend in dit rapport, dit zou verklaard kunnen worden door leklucht. Na een eerste indicatieve meting bleek de drukkamer nog op 
veel plekken niet dicht, wat een hogere stofconcentratie veroorzaakte in de drukkamer. Nadat dit is opgelost zijn er reducties gemeten tot $98 \%$, hieruit blijkt dat het mogelijk is een groot deel van het stof te reduceren overeenkomstig met andere meetrapporten. De lagere gemeten reducties zouden kunnen worden verklaard door leklucht via een toegangsluik naar de drukkamer. Dit luik wordt aangetrokken door de onderdruk die ontstaat in de drukkamer. Dit zou ook kunnen verklaren dat er een negatief effect is gevonden op het reductiepercentage door het ventilatiedebiet. Een hoger ventilatiedebiet betekend een hogere onderdruk in de drukkamer en eventueel meer leklucht via verschillende wegen, waaronder het toegangsluik. Voor een goede werking van dit systeem is het van groot belang dat alle ventilatielucht de stal verlaat via de absoluutfilters.

Neveneffecten en afwenteling

$\mathbf{P M}_{2.5}$

In dit onderzoek zijn geen metingen verricht naar de reductie van $\mathrm{PM}_{2.5}$. In het eerder genoemde meetrapport van Het Labor für Arbeits- und Umwelthygiene is onderzoek gedaan naar deeltjes van 0,3-1,0 $\mu \mathrm{m}, 1,0-10,0 \mu \mathrm{m}$ en groter dan 10,0 $\mathrm{mm}$. Het filter reduceerde 10,8\% van de deeltjes in het kleinste bereik en het filtermateriaal bleek meer dan $98 \%$ van de deeltjes groter dan $1,0 \mu \mathrm{m}$ tegen te houden (Missel, 2017). Het meetrapport van LUFA Nord-West geeft een reductie van meer dan $96 \%$ voor $\mathrm{PM}_{2.5}$ (Stevens, 2014). Hieruit blijkt dat de efficiëntie van de filters waarschijnlijk lager is voor deeltjes kleiner dan $\mathrm{PM}_{2.5}$.

\section{Vertaling naar andere pluimveecategorieën}

Deze techniek met filter is reeds opgenomen in de lijst "E 7 Additionele technieken voor emissiereductie van fijnstof" met $50 \%$ reductie bij gespecificeerde ventilatiedebieten voor de verschillende diercategorieën ( $E, F$ en $G$ ). Er is geen reden om aan te nemen dat de reductie minder wordt bij het volledig filteren van de ventilatielucht door de absoluutfilters. Daarom kan de techniek in deze vorm ook worden toegepast bij de categorieën E, F en G. 


\section{$5 \quad$ Conclusie}

De absoluutfilters van Inno ${ }^{+}$Plettenburg is in staat de emissie van $\mathrm{PM}_{10}$ in leghennenstallen te reduceren. Op grond van acht metingen zowel voor als achter het filter in één leghennenstal, waarbij de relevante meetprotocollen zoveel mogelijk zijn gevolgd, bedraagt deze reductie gemiddeld $76 \%$. Deze reductie is statistisch significant verschillend van nul. Rekening houdend met een onzekerheidsmarge van 10 procentpunten vanwege het meten op slechts één bedrijfslocatie, is het advies om een reductiepercentage op te nemen van 66\%. Het lagere reductiepercentage dan haalbaar wordt waarschijnlijk voornamelijk veroorzaakt door leklucht tussen de dierruimtes en de drukkamer voor de ventilatoren. 


\section{Literatuur}

Aarnink, A.J.A., Cambra-López, M., Lai, H.T.L., Ogink, N.W.M. 2011. Deeltjesgrootteverdeling en bronnen van stof in stallen. Rapport 452. Lelystad: Wageningen UR Livestock Research.

Cambra-López, M., Winkel, A., Van Harn, J., Ogink, N. W. M., \& Aarnink, A. J. A. (2009). Ionization for reducing particulate matter emissions from poultry houses. Transactions of the ASABE, 52(5), 1757-1771.

Cambra-Lopez, M. ; Winkel, A. ; Mosquera Losada, J. ; Ogink, N.W.M. ; Aarnink, A.J.A. 2015. Comparison between light scattering and gravimetric samplers for PM10 mass concentration in poultry and pig houses. Atmos. Environ. 111:20-27. Lelystad: Wageningen UR Livestock Research.

CEN. 2014. Ambient air - Standard gravimetric measurement method for the determination of the PM10 or PM2,5 mass concentration of suspended particulate matter. Brussel, Belgie: European Committee for Standardization (CEN).

CIGR. 2002. 4th Report of Working Group on Climatization of animal houses. Heat and moisture production at animal and house levels (eds. Pedersen, S. and K. Sällvik). International Commission of Agricultural Engineering (CIGR), Section II.

Feijter de, M. P., \& Reijman, P. B. (2014). Brandveiligheid stofafvangsystemen in kippenstallen. Efectis Nederland.

Gezondheidsraad. 2018. Gezondheidswinst door schonere lucht. Den Haag: Gezondheidsraad.

Hagenaars, T., Hoeksma, P., de Roda-Husman, A.M., Swart, A., Wouters, I. 2017. Veehouderij en Gezondheid Omwonenden (aanvullende studies). Analyse van gezondheidseffecten, risicofactoren en uitstoot van bioaerosolen. Rapport 2017-0062. Bilthoven: RIVM.

Heederik D.J.J. \& IJzermans, C.J.. 2011. Mogelijke effecten van intensieve-veehouderij op de gezondheid van omwonenden: onderzoek naar potentiële blootstelling en gezondheidsproblemen. Utrecht: IRAS-UU. Utrecht: NIVEL. Bilthoven: RIVM.

Heederik, D., Erbrink, H., Farokhi, A., Hagenaars, T., Hoek, G., Ogink, N., de Rooij, M., Smit, L., Winkel, A., Wouters, I. Risicomodellering veehouderij en gezondheid (RVG): modellering van regionale endotoxineconcentraties en relaties met gezondheidseffecten. Rapport IRAS UU 2019-01 / WBVR-1910304. Utrecht: Institute for Risk Assessment Sciences. Lelystad: Wageningen Bioveterinary Research.

Hendriks, C., Kranenburg, R., Kuenen, J., van Gijlswijk, R., Wichink Kruit, R., Segers, A., Denier van der Gon, H., Schaap, M. 2013. The origin of ambient particulate matter concentrations in the Netherlands. Atmos. Environ. 69:289-303.

IJzermans, C.J., Smit, L.A.M., Heederik, D.J.J., Hagenaars, T.J. 2018. Veehouderij en gezondheid omwonenden III: longontsteking in de nabijheid van geiten- en pluimveehouderijen; actualisering van gegevens uit huisartspraktijken 2014-2016. Utrecht: NIVEL.

Maassen, K., Smit, L., Wouters, I., van Duijkeren, E., Janse, I., Hagenaars, T., IJzermans, J., van der Hoek, W., Heederik, D. 2016. Rapport 2016-0058. Bilthoven, Nederland: RIVM.

Missel, T. 2017. Staub- und Endotoxinbelastung der Broilerstallabluft hinter einer Wärmerückgewinnungsanlage "Earny" der Big Dutchman International GmbH. Labor für Arbeitsund Umwelthygiene, Gutachten Nr. 0417/14.

Ogink, N. W. M., P. Hofschreuder, A. J. A. Aarnink. 2011. Protocol voor meting van fijnstofemissie uit huisvestingssystemen in de veehouderij 2010. Rapport 492. Lelystad: Wageningen University and Research Centre, Livestock Research.

Ogink, N.W.M., Mosquera, J., Hol, J.M.G., 2017. Protocol voor meting van ammoniakemissie uit huisvestingssystemen in de veehouderij 2013a. Wageningen Livestock Research, Rapport 1032.

Pedersen, S., Blanes-Vidal, V., Joergensen, H., Chwalibog, A., Haeussermann, A., Heetkamp, M.J.W., Aarnink, A.J.A. 2008. Carbon dioxide production in animal houses: a literature review. Agricultural Engineering International: CIGR Ejournal, Vol. X, December 2008. Manuscript BC 08008.

Rijksoverheid. 2018. Emissiefactoren fijn stof voor veehouderij. Excelfile online gepubliceerd 15-032018. Online beschikbaar op: https://www.rijksoverheid.nl/documenten/publicaties/2018/03/15/emissiefactoren-fijn-stof-voorveehouderij-2018. 
Rijksoverheid. 2019. Bijlage 1, bedoeld in artikel 2, eerste lid, van de Regeling ammoniak en veehouderij. Versie 26 april 2019. Online beschikbaar op: https://wetten.overheid.nl/BWBR0013629/2019-04-26\#Bijlage1.

RIVM. 2019. Stations. Online beschikbaar op: https://www.luchtmeetnet.nl/stations/alleprovincies/alle-gemeentes/alle-stoffen

Stevens, R. 2014. Bericht über die Durchführung von Emissionsmessungen an einem Hähnchenmaststall mit Wärmetauscher sowie einem Referenzstall. LUFA Nord-West, Projekt-Nr.: 20120208-838.

VERA. 2018a. Vera test protocol for air cleaning technologies. Version 2:2018-09. Delft, the Netherlands: International VERA Secretariat.

VERA. 2018b. Vera test protocol for livestock housing and management systems. Version 3:2018-09. Delft, the Netherlands: International VERA Secretariat.

VSN. 2018. GenStat reference manual (release 19). Hemel Hempstead, UK: VSN International Ltd.

WHO. 2015. WHO Air quality guidelines for particulate matter, ozone, nitrogen dioxide and sulfur dioxide - Global update 2005. Geneva, Switzerland: World Health Organization.

Winkel, A., Emous, R.A. van, Kwikkel, R.K., Ogink, N.W.M., Aarnink, A.J.A. 2009. Maatregelen ter vermindering van fijnstofemissie uit de pluimveehouderij: ionisatie bij leghennen in volièrehuisvesting. Rapport 203. Lelystad: Animal Sciences Group, Wageningen UR.

Winkel, A., Nijeboer, G.M., Huis in 'T Veld, J.W.H., Ogink, N.W.M. 2013. Maatregelen ter vermindering van fijnstofemissie uit de pluimveehouderij: validatie van een ionisatiesysteem op leghennenbedrijven. Rapport 685. Lelystad: Wageningen UR Livestock Research.

Winkel, A., Wouters, I.M., Aarnink, A.J.A., Heederik, D.J.J., Ogink, N.W.M. 2014. Emissies van endotoxinen uit de veehouderij: een literatuurstudie voor ontwikkeling van een toetsingskader. Rapport 773. Wageningen: Wageningen Livestock Research.

Winkel, A., Llorens Rubio, J., Huis in 't Veld, J.W.H., Vonk, J.A., Ogink, N.W.M. 2015a. Equivalence testing of filter-based, beta-attenuation, TEOM, and light-scattering devices for measurement of $\mathrm{PM}_{10}$ concentration in animal houses. J. Aeros. Sci. 80:11-26.

Winkel, A., Mosquera Losada, J., Groot Koerkamp, P.W.G., Ogink, N.W.M., Aarnink, A.J.A. 2015b Emissions of particulate matter from animal houses in the Netherlands. Atmos. Environ. 111:202212.

Winkel, A. 2016. Particulate matter emission from livestock houses: measurement methods, emission levels and abatement systems. PhD Thesis. Wageningen, the Netherlands: Wageningen University \& Research.

Winkel, A., Mosquera Losada, J., Aarnink, A.J.A., Groot Koerkamp, P.W.G., Ogink, N.W.M. 2016. Evaluation of oil spraying systems and air ionisation systems for abatement of particulate matter emission in commercial poultry houses. Biosyst. Eng. 150:104-122.

Winkel, A. 2020. Berekening van een onzekerheidsmarge voor fijnstof reducerende technieken bemeten bij één in plaats van twee bedrijfslocaties. Wageningen Livestock Research, Rapport 1239. 


\section{Bijlage 1 Beschrijving stal}

\begin{tabular}{|c|c|}
\hline Kenmerk & Beschrijving \\
\hline \multicolumn{2}{|l|}{ Stal } \\
\hline Bouwjaar & 2017 \\
\hline Rav code en omschrijving & $\begin{array}{l}\text { E } 2.11 .3 \text { volièrehuisvesting, } 30-35 \% \text { van de leefruimte } \\
\text { roosters met daaronder een mestband met } 0,7 \mathrm{~m}^{3} \text { per dier } \\
\text { per uur mestbeluchting. Mestbanden minimaal eenmaal } \\
\text { per week afdraaien. Roosters minimaal in twee etages } \\
\text { (BWL } 2005.04 . \mathrm{V} 1 \text { ) }\end{array}$ \\
\hline \multirow[t]{3}{*}{ Emissiefactoren (nog niet bekend) } & Emissie $\mathrm{PM}_{10}: 65 \mathrm{~g} /$ dierplaats per jaar \\
\hline & Emissie ammoniak: $0,037 \mathrm{~kg} /$ dierplaats per jaar \\
\hline & Emissie geur: $0,34 \mathrm{OU}_{\mathrm{E}} /$ dierplaats per seconde \\
\hline Afmetingen $\left(\mathrm{l} \times \mathrm{b} \times \mathrm{h}_{\text {goot }} / \mathrm{h}_{\text {nok }}\right)$ & $100 \times 24$ m (gebouw), $100 \times 8$ m (uitloop $\times 2$ ) \\
\hline Oriëntatie van de stal & Oost (voorgevel) - West (achtergevel) \\
\hline \multicolumn{2}{|l|}{ Dieren } \\
\hline Aantal hennen bij opzet & 24.000 \\
\hline $\begin{array}{l}\text { Bezettingsgraad bij opzet } \\
\text { Merk hen }\end{array}$ & $\begin{array}{l}\text { Totaal oppervlak } 4000 \mathrm{~m}^{2}=6 \text { hennen per } \mathrm{m}^{2} \\
\text { Dekalb wit }\end{array}$ \\
\hline \multicolumn{2}{|l|}{ Klimaatregeling } \\
\hline Beschrijving luchtinlaat & $\begin{array}{l}\text { Via openingen in beide zijgevels, over de lengte van de } \\
\text { stal, tussen beide nachtverblijven en uitloop komt de lucht } \\
\text { de stal binnen. Daarnaast is er mestbandbeluchting } \\
\text { aanwezig. }\end{array}$ \\
\hline Beschrijving luchtuitlaat & $\begin{array}{l}\text { Een deel van de lucht in beide nachtverblijven wordt via } \\
\text { gevelventilatoren naar de ruimte voor de tunnel geblazen. } \\
\text { Wanneer de binnentuin open is voor de hennen zal de } \\
\text { meeste lucht via de binnentuin naar de achtergevel } \\
\text { worden gezogen. Een deel van deze lucht gaat via } 4 \text { grote } \\
\text { stoffilters naar de uitlaatruimte. Een ander deel wordt in } \\
\text { de ruimte voor de droogtunnel geblazen. Deze lucht gaat } \\
\text { via de droogtunnel naar de ruimte na de tunnel en van } \\
\text { hier gaat deze lucht via zes stoffilters naar de } \\
\text { uitlaatruimte. In de gevel van de uitlaatruimte zijn negen } \\
\text { dakventilatoren aanwezig voor de afvoer van de lucht naar } \\
\text { buiten. }\end{array}$ \\
\hline Ventilatieregeling & Op basis van staltemperatuur en onderdruk \\
\hline Streeftemperatuur & (1) \\
\hline Verwarmingssysteem & $\begin{array}{l}\text { Wisselaar + pomp, ingezet voor opwarmen lucht voor } \\
\text { mestbandbeluchting. }\end{array}$ \\
\hline \multicolumn{2}{|l|}{ Bedrijfsvoering } \\
\hline Beschrijving houderijsysteem & $\begin{array}{l}\text { Centraal in de stal ligt een binnentuin die voor de hennen } \\
\text { toegankelijk is van 10:00 tot 19:30 uur. Aan weerszijden } \\
\text { van de binnentuin zijn } 2 \text { nachtverblijven aanwezig met } \\
\text { etages en nestkasten. Via de nachtverblijven kunnen de } \\
\text { hennen overdag naar de buitenrennen (vrije uitloop) aan } \\
\text { beide kanten van de stal (afgesloten tijdens de } \\
\text { meetdagen). }\end{array}$ \\
\hline Beschrijving voersysteem & In beide nachtverblijven 3 voerlijnen \\
\hline Voertijden & $\begin{array}{l}4: 00-7: 00-8: 00-10: 30-13: 00-15: 30-18: 00- \\
19: 00 \text { uur }\end{array}$ \\
\hline Voer & $\begin{array}{l}\text { Speciaal ontwikkeld kippenvoer uit restanten van } \\
\text { bijvoorbeeld bakkerijen. Het voer bestaat voor } 97 \% \text { uit } \\
\text { restjes en } 3 \% \text { uit vitaminen en mineralen }\end{array}$ \\
\hline Beschrijving drinkwatersysteem & $\begin{array}{l}\text { Waterlijnen met drinknippels en lekschoteltjes: } 3 \text { lijnen in } \\
\text { beide nachtverblijven }\end{array}$ \\
\hline Drinktijden & $11: 00$ en $20: 00$ uur \\
\hline Strooiselmanagement & Houtkrullen $(2 \mathrm{~cm})+$ mest + luzerne \\
\hline Beschrijving verlichting & Daglicht + LED-licht als het buiten donker is \\
\hline Lichtregime & $16 L: 8 D$ \\
\hline Schoonmaakregime & Nat reinigen en ontsmetten \\
\hline \multicolumn{2}{|l|}{ Productiecyclus } \\
\hline Leeftijd bij opzet & 17 weken \\
\hline Leeftijd bij ruimen & 85 weken \\
\hline Leegstand tussen koppels & 1 week \\
\hline
\end{tabular}




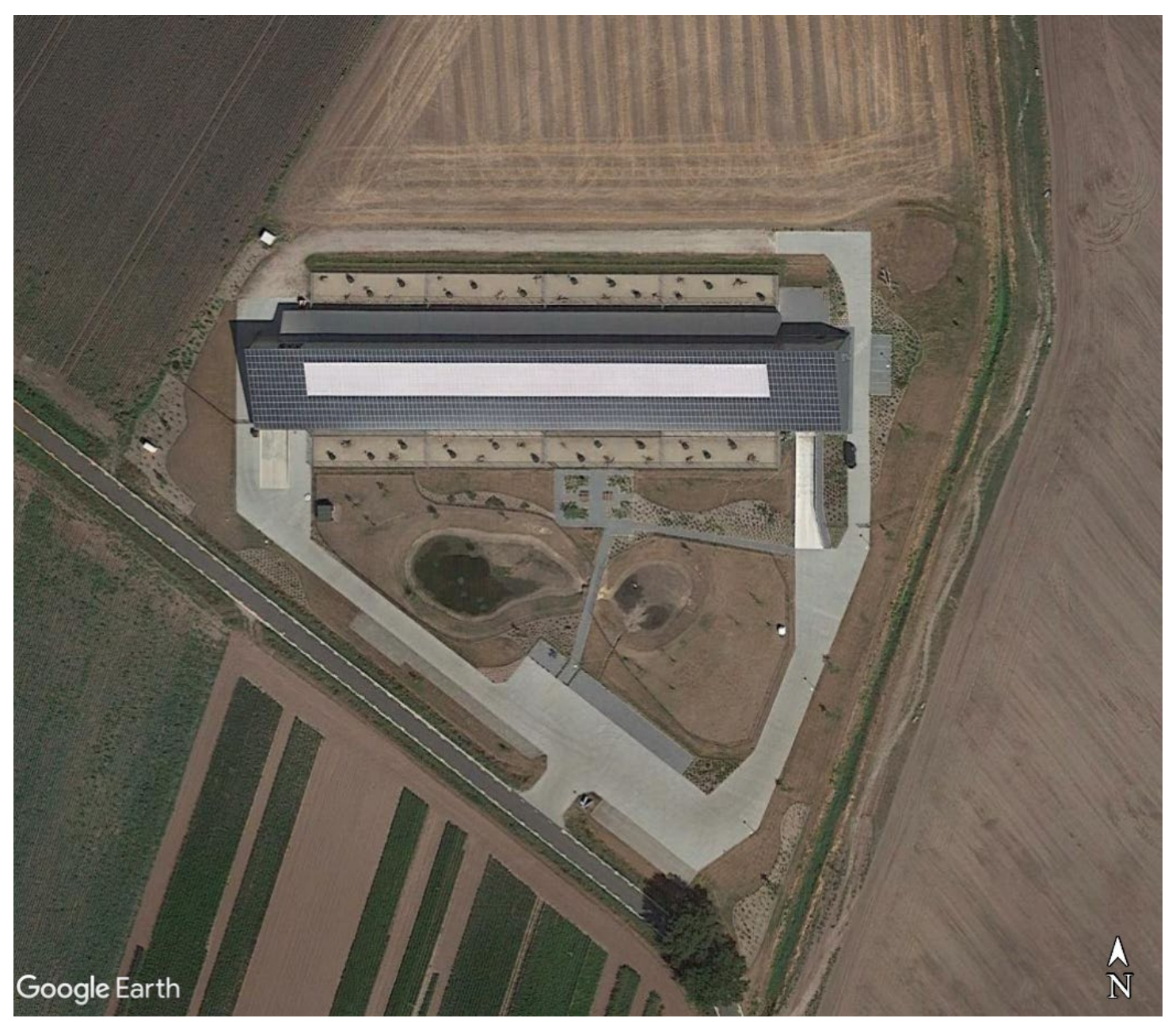

Luchtfoto bedrijf, met in het midden van de foto de stal en hierboven en onder de uitlopen. In het midden van de stal is het glazen dak van de binnentuin te zien.

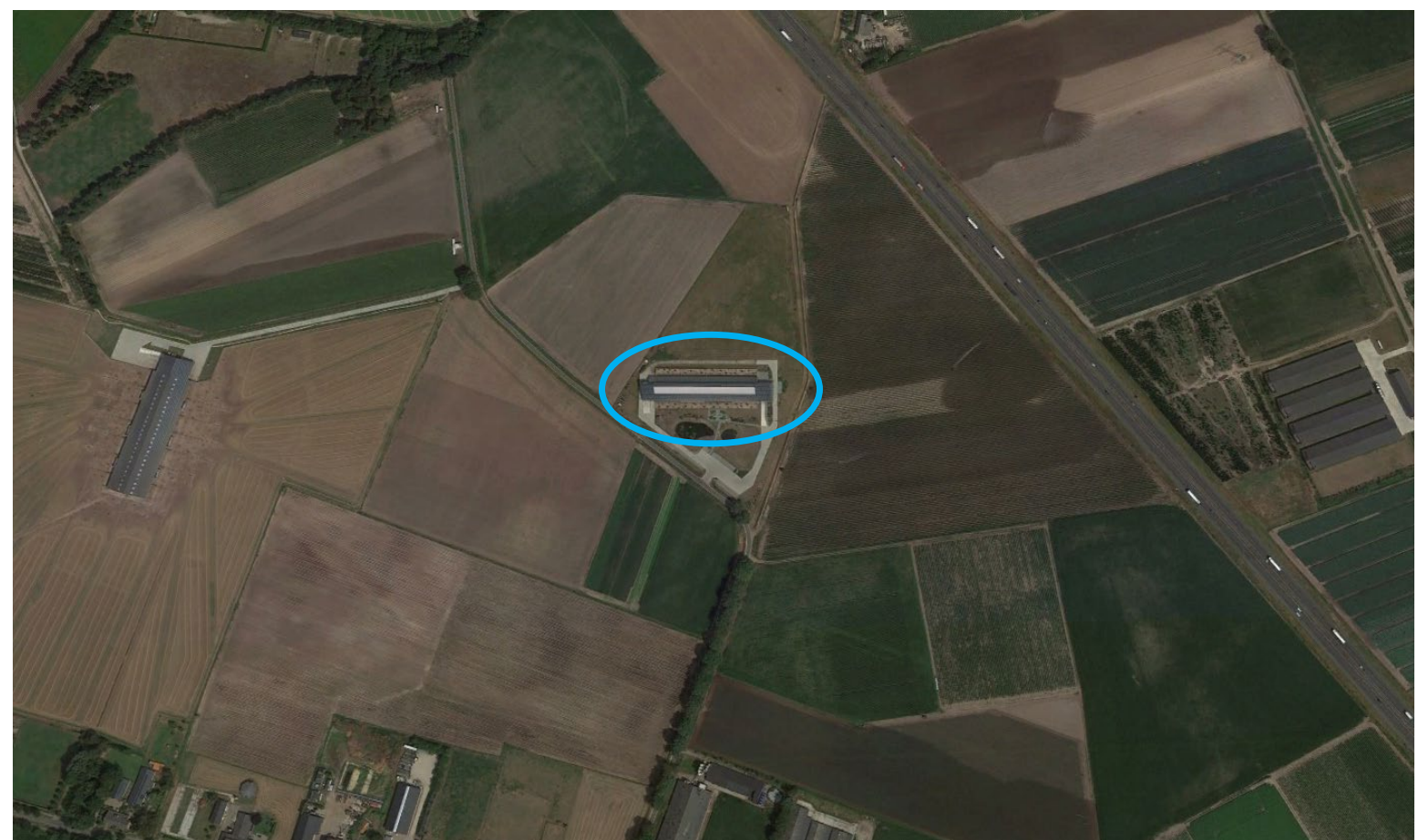

Luchtfoto bedrijf(blauw omcirkeld) met wijdere omgeving. Ten noordoosten van het bedrijf loopt een snelweg en in de omgeving zijn meerdere andere veehouderijen te vinden, waaronder een pluimveehouderij. 


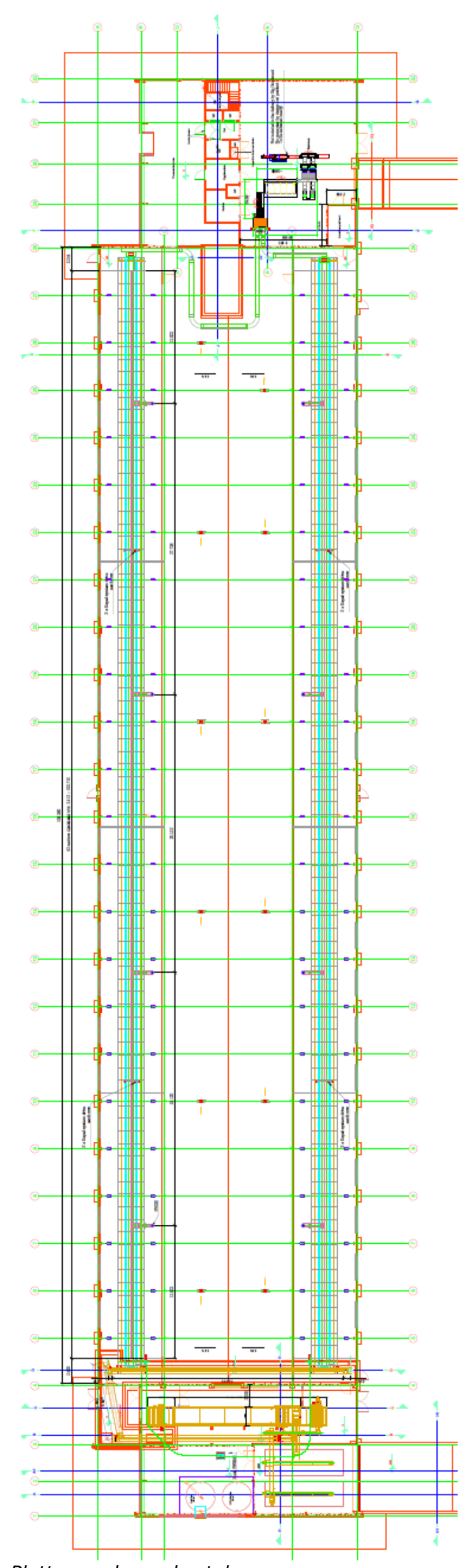

Plattegrond van de stal. 


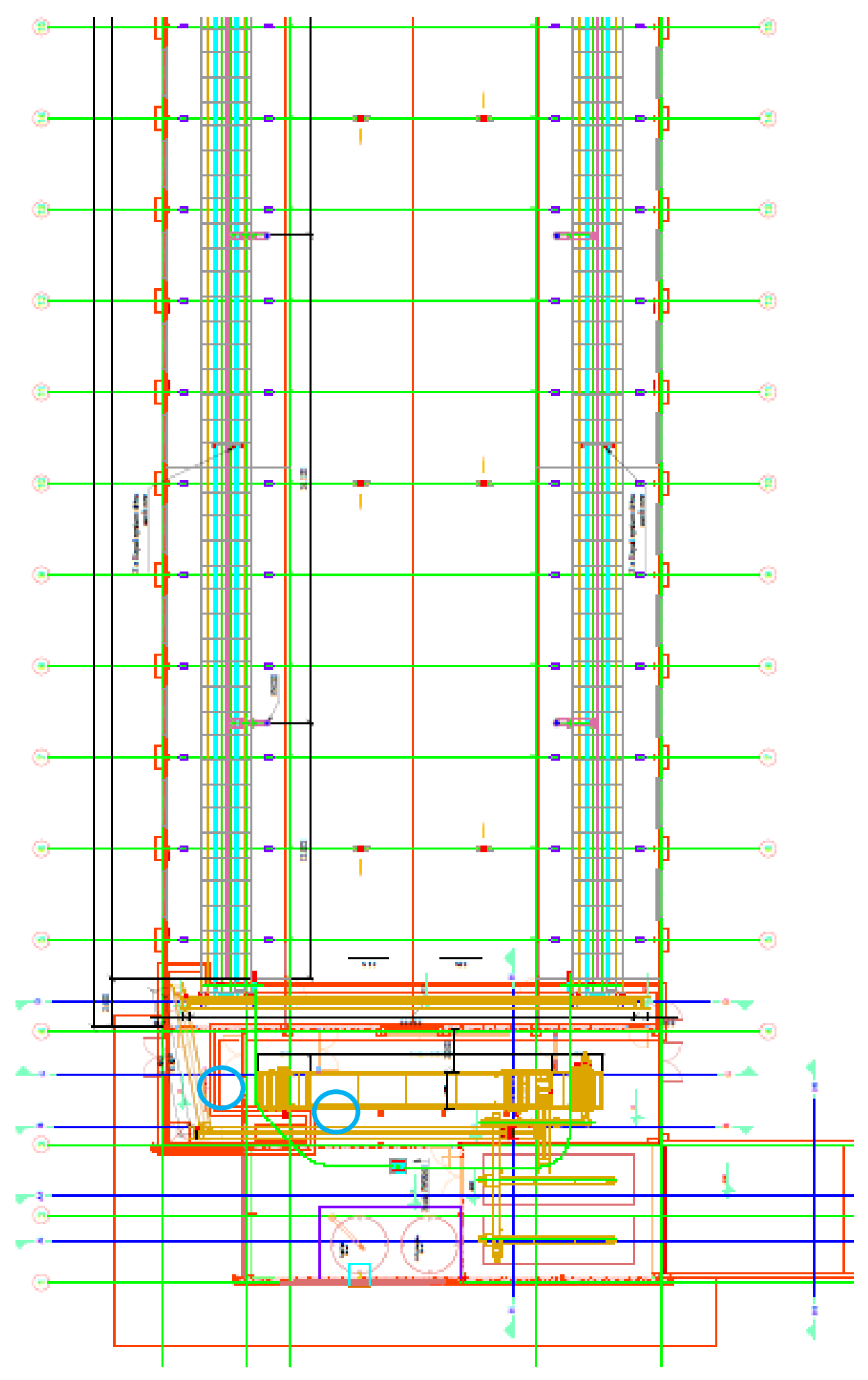

Ingezoomde plattegrond van de stal. De locatie van de metingen bij de filters is aangegeven met de blauwe cirkels. De linker blauwe cirkel is het meetpunt na de filters, vlak voordat de lucht de stal verlaat. De rechter blauwe cirkel is na de droogtunnel (geel), de lucht gaat vanaf hier naar de filters. 


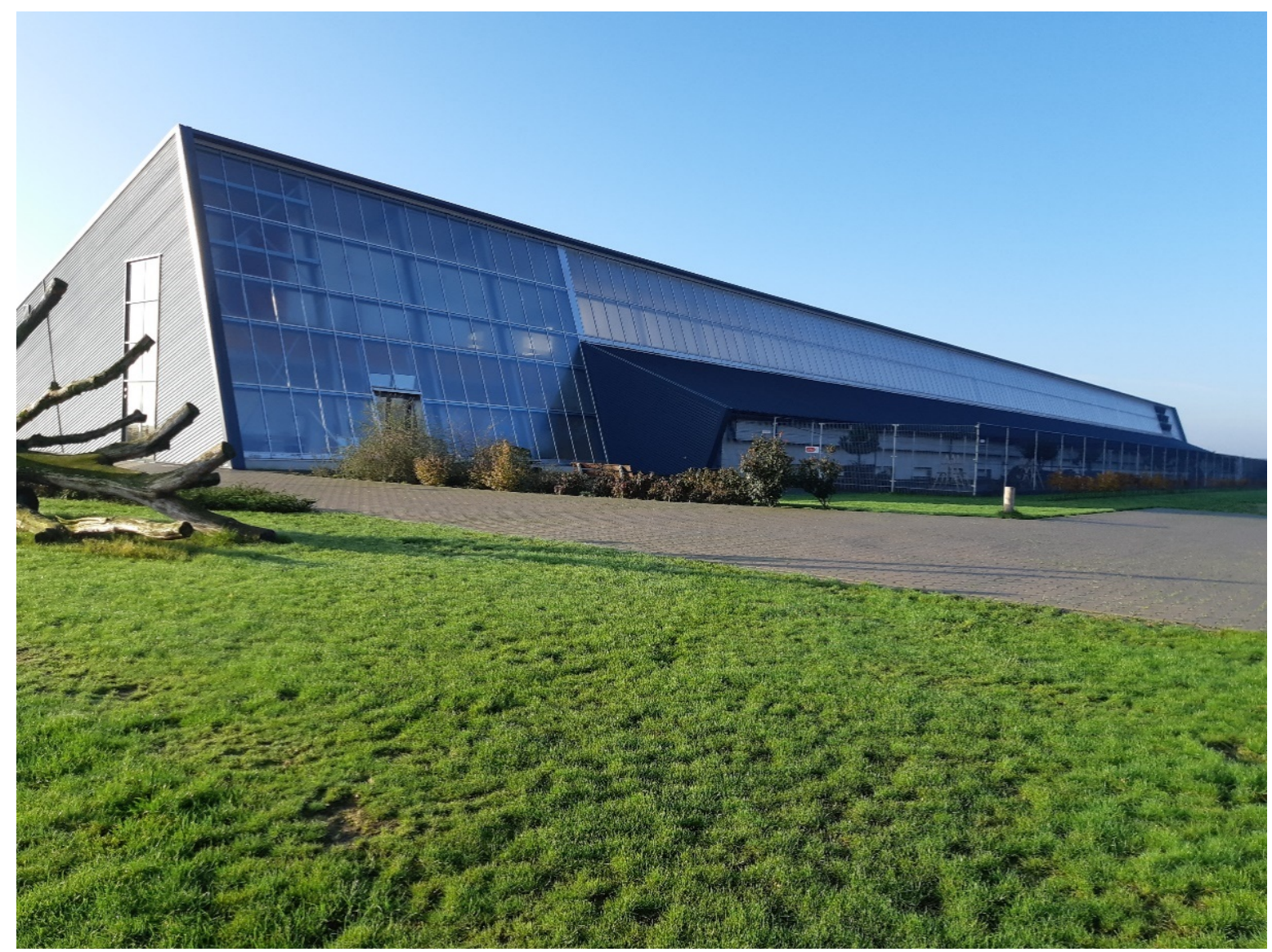

Foto noordzijde stal

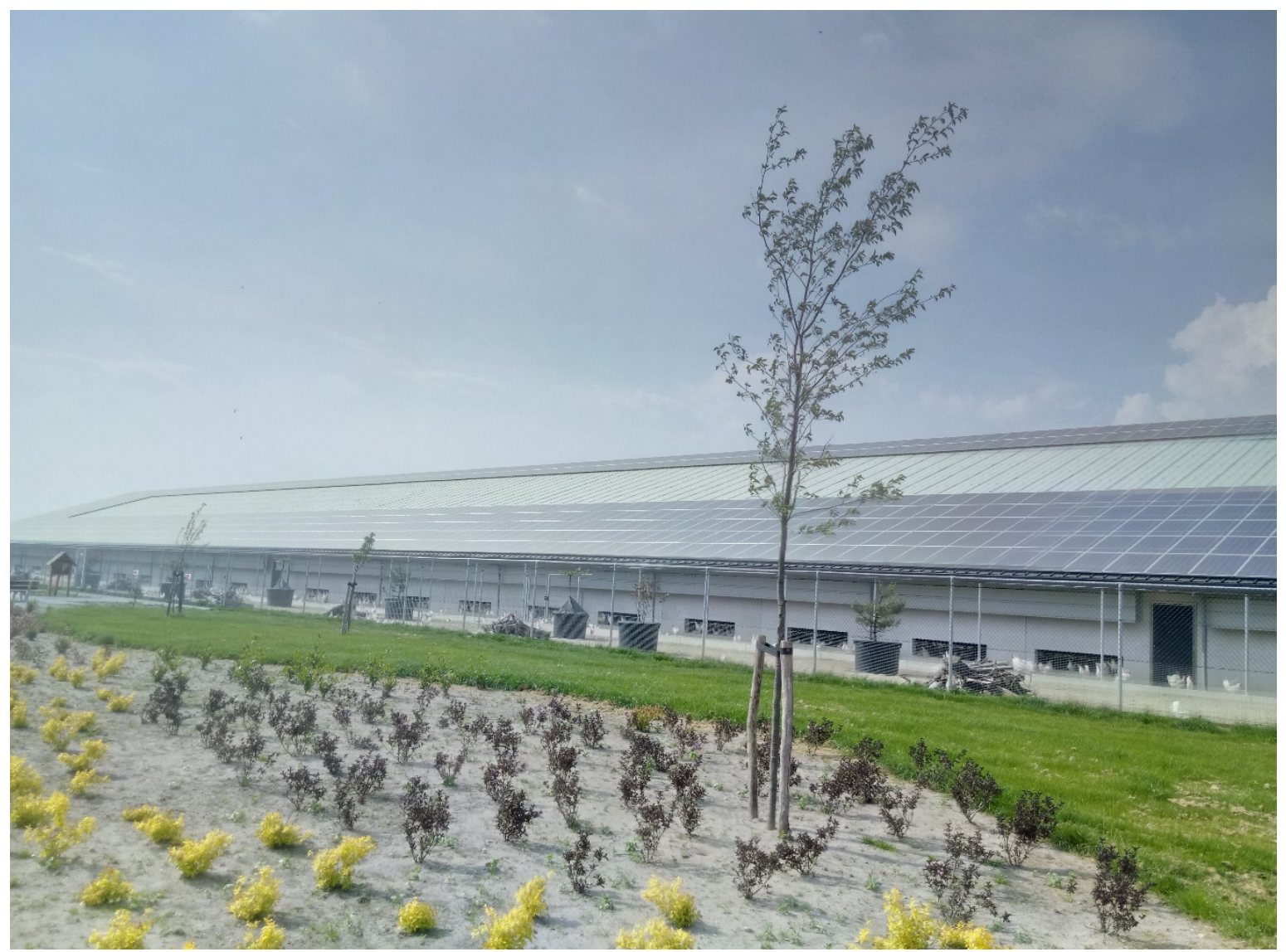

Foto zuidzijde stal met vrije uitloop (niet in gebruik tijdens meetdagen). 


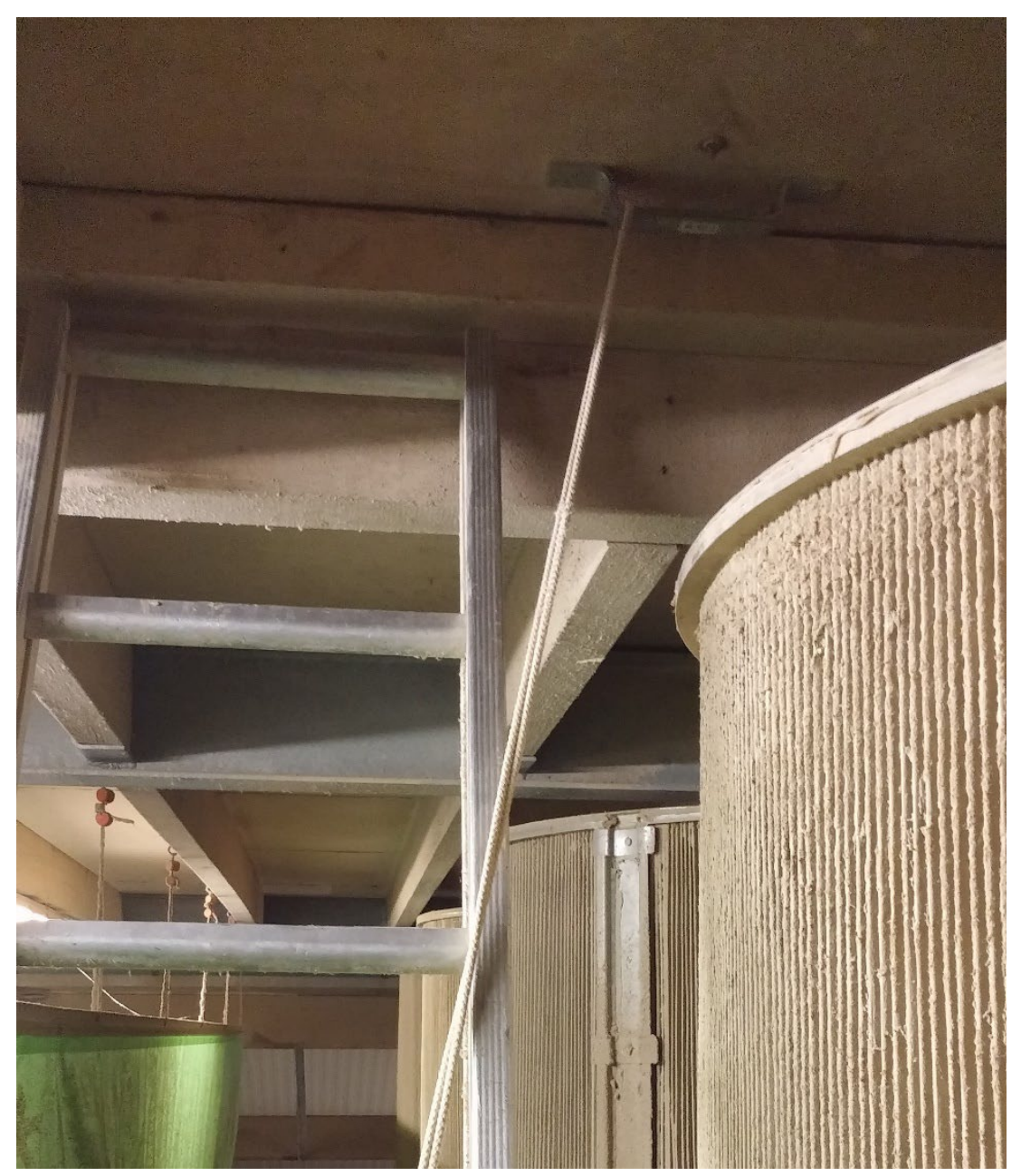

Foto absoluutfilters boven droogtunnel.

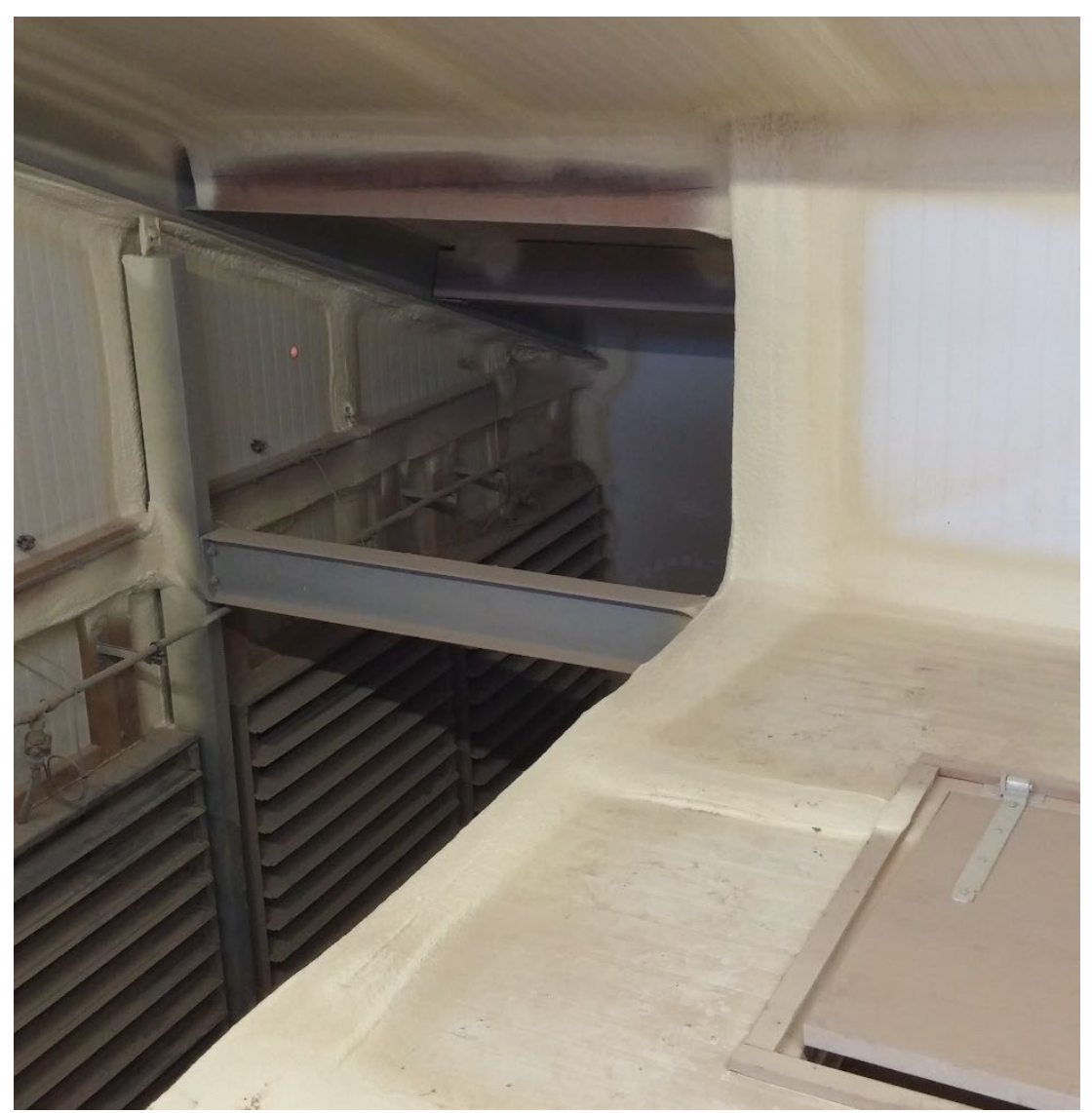

Foto van achterzijde filters en drukkamer 


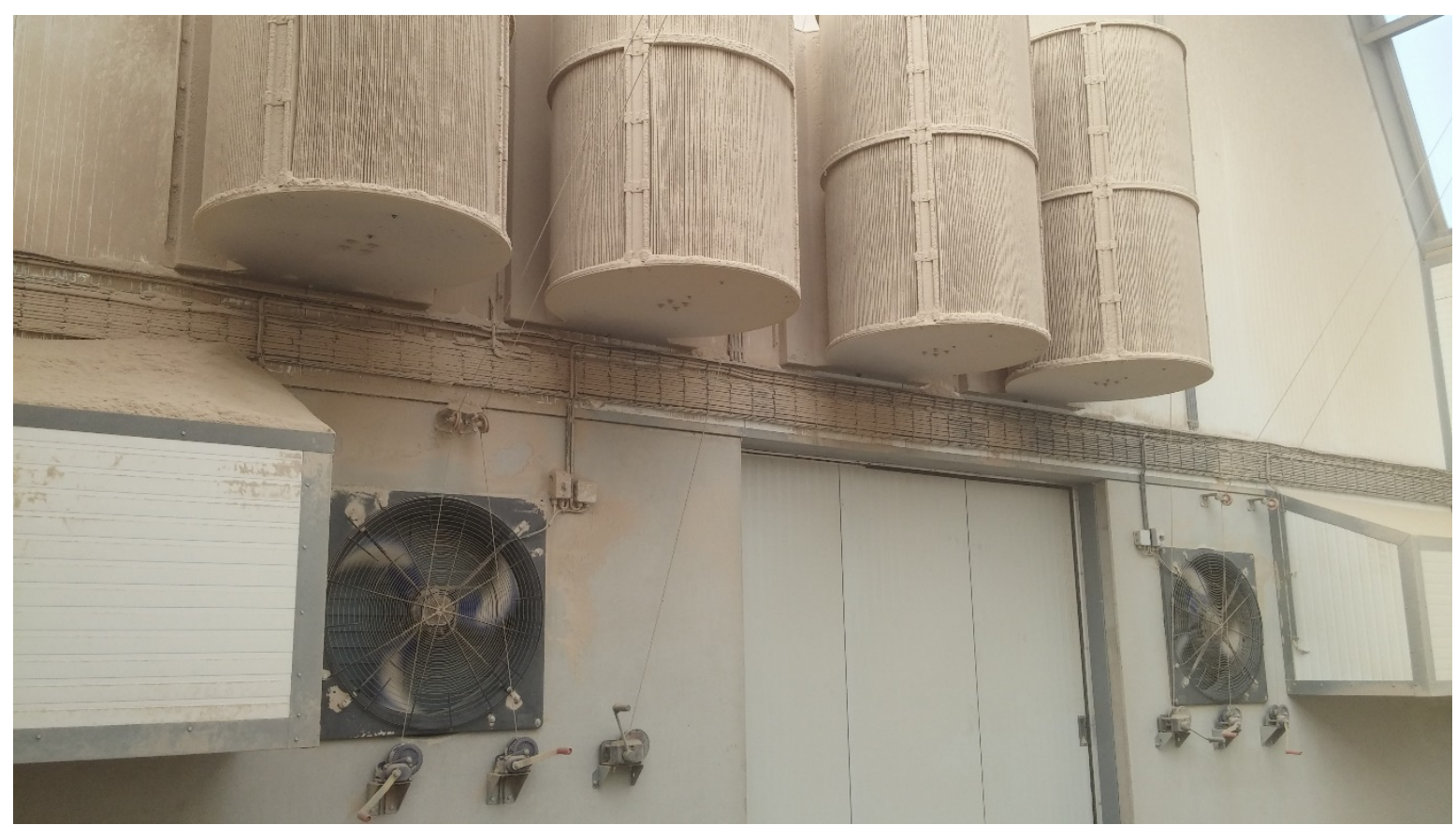

Achterwand binnentuin met ventilatoren naar de droogtunnel, aanzuigkanalen vanuit de nachthokken naar de droogtunnel en absoluutfilters naar drukkamer met hoofdventilatoren.

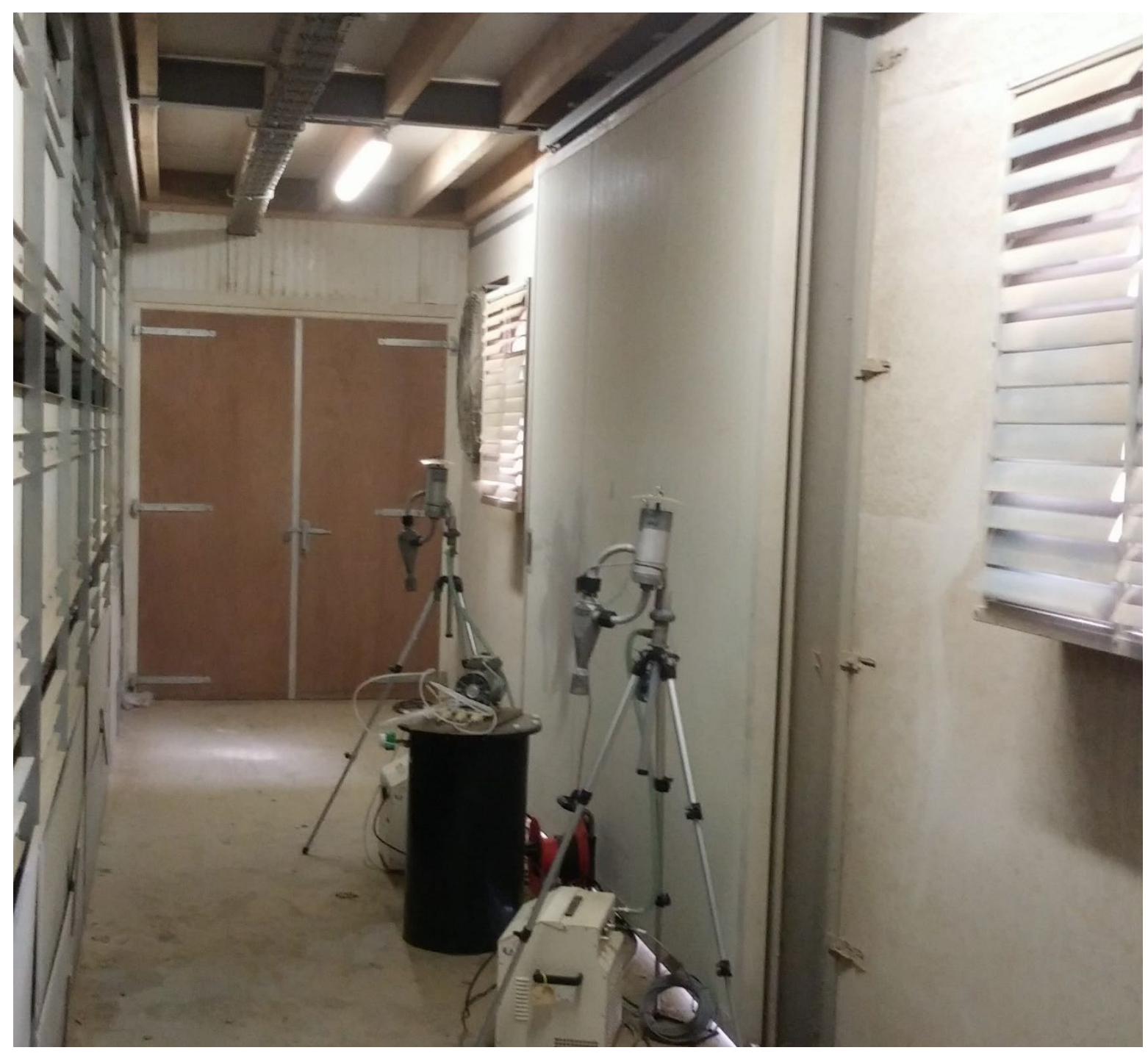

Plaats van metingen voor de droogtunnel. 


\section{Bijlage 2 Landbouwkundige voorwaarden}

\begin{tabular}{|c|c|c|}
\hline Onderdeel & Landbouwkundige voorwaarde: & Voldoet \\
\hline Huisvesting & $\begin{array}{l}\text { Tijdens de meetperiode wordt voldaan aan de geldende } \\
\text { dierwelzijnsnormen. } \\
\text { Vóór de meetperiode moet de stal minstens twee maanden gebruikt zijn } \\
\text { voor de huisvesting van legkippen. }\end{array}$ & $\begin{array}{l}\mathrm{Ja} \\
\mathrm{Ja}\end{array}$ \\
\hline Klimaat & $\begin{array}{l}\text { De legkippen worden gehouden onder zodanige omstandigheden dat de } \\
\text { CO2-concentratie in de lucht van de afdeling onder de } 3.000 \text { ppm blijft. }\end{array}$ & $\begin{array}{l}\text { Op één kleine } \\
\text { overschrijding na }\end{array}$ \\
\hline Voeding & $\begin{array}{l}\text { De kippen krijgen een gangbaar voerschema (CVB) met minimaal } 14 \mathrm{~g} \\
\text { RE/omzetbare energie leghennen (OEIh in MJ/kg) in het voer. Het } \\
\text { voerverbruik per aanwezige legkip vanaf } 20 \text { weken dient minimaal } 105 \\
\text { g per dier per dag te zijn. Waterverstrekking gebeurt onbeperkt. } \\
\text { Verklaring van geen gebruik van diervoedertoevoegingsmiddelen die } \\
\text { mogelijk als hoofd- of nevenwerking een verlagend effect hebben op de } \\
\text { pH van de urine en/of de ureumuitscheiding via de urine. }\end{array}$ & $\begin{array}{l}\text { Ja, deze gehalten } \\
\text { hebben geen effect op } \\
\text { fijnstofemissie } \\
\\
\text { Ja, deze gehalten } \\
\text { hebben geen effect op } \\
\text { fijnstofemissie }\end{array}$ \\
\hline Productie & De eiproductie moet op jaarbasis minimaal 300 eieren/kip zijn. & $\mathrm{Ja}$ \\
\hline $\begin{array}{l}\text { Gezondheid } \\
\text { en hygiëne }\end{array}$ & $\begin{array}{l}\text { De legkippen krijgen standaard veterinaire zorg. Het uitvalspercentage } \\
\text { mag niet hoger zijn dan } 10 \% \text { in de volledige productieperiode. }\end{array}$ & $\begin{array}{c}\text { Nee, dit heeft echter } \\
\text { nauwelijks invloed op } \\
\text { het reductiepercentage }\end{array}$ \\
\hline $\begin{array}{l}\text { Aantal } \\
\text { dieren }\end{array}$ & De groepsgrootte bedraagt minimaal 750 & $\mathrm{Ja}$ \\
\hline Registratie & \begin{tabular}{|l} 
Gedurende vier weken voorafgaand aan de meting: \\
- totaal aantal kg verstrekt voer in de afdeling/stal \\
- totaal aantal kg verstrekt strooisel in de afdeling/stal \\
- totale hoeveelheid waterverbruik in de meetafdeling/stal \\
- aanwezige + ingaande en uitgaande dieren (ook tijdens de meting) \\
Tijdens de meting: \\
- productie: aantal eieren, eigewicht en uitval \\
- voeropname \\
- tijdstippen van verwijderen van (drijf)mest uit de afdeling/stal \\
- registratie van voersamenstelling \\
- cO2-concentratie \\
- de wijze waarop voldaan wordt aan tijdens de meetperiode \\
geldende dierwelzijnsnormen
\end{tabular} & $\begin{array}{c}\text { Nee, deze kengetallen } \\
\text { hebben nauwelijks } \\
\text { effect op de reductie } \\
\text { van fijnstof }\end{array}$ \\
\hline
\end{tabular}




\section{Bijlage 3 Kalibratie meetapparatuur}

Fijnstof-analyse $P M_{10}$

DustTrak Aerosol Monitor Model 8520 en DustTrak II Aerosol Monitor Model 8530.

Alle gebruikte instrumenten hebben een recent certificaat van de leverancier. Na iedere stalmeting van ruim 2 × 24 uur zijn de instrumenten van buiten en binnen goed schoon gemaakt en indien nodig weer van een nieuw filter voorzien. Dit laatste geeft het instrument zelf aan.

Vervolgens hebben de instrumenten in het luchtlaboratorium gedurende enkele dagen in de zogenaamde survey-mode gedraaid. Hierbij wordt het instrument gespoeld met de relatief schone omgevingslucht. Middels een 'nul-filter' is gecontroleerd of de zero-waarde moest worden aangepast. Bij model 8520 werd voor iedere meting de nieuwe nul-waarde ingevoerd. Bij model 8530 is het nullen van het toestel lastiger en is gekozen om de actuele nulwaarden te noteren en later, tijdens de gegevensverwerking voor de hogere nulwaarde te corrigeren. Na circa 3 dagen spoelen zijn de instrumenten uitgezet en klaargezet voor de volgende metingen.

De instrumenten worden jaarlijks teruggestuurd naar de leverancier voor onderhoud en justeren, gekoppeld aan een nieuw certificaat. Als op basis van de verkregen ruwe data blijkt dat de instrumenten niet betrouwbaar zijn, worden deze geëxcludeerd van de dataset voor verdere bewerking. Door een meettechnicus wordt vervolgens beoordeeld of het instrument moet worden opgestuurd voor justering. Bij herhaling van onbetrouwbare data bij een volgende meting zal het instrument zeker opgestuurd worden.

\section{$\mathrm{CO}_{2}$-analyse}

Testo type 435 met IAQ-probe voor $\mathrm{CO}_{2}$ en Vaisala $\mathrm{CO}_{2}$-sensor met Carbon Dioxide Probe GMP252.

De instrumenten hebben recente certificaten van de leverancier. Voordat de instrumenten in het onderzoek werden ingezet zijn ze geijkt in het eigen luchtlaboratorium. Middels het aanbieden van een verdunningsreeks $\mathrm{CO}_{2}$-kalibratiegas is de ijklijn van ieder instrument vastgesteld.

De Testo werd op een gegeven ogenblik instabiel en is daarna, na een gezamenlijke overbruggingsperiode, vervangen door de Vaisala-sensoren. De Vaisala-sensoren hebben geen eigen opslaggeheugen en zijn daardoor ingezet in combinatie met Koenders dataloggers.

\section{Temperatuur en relatieve luchtvochtigheid}

Escort RH iLogger EI-HS-D-32-L.

De logger staat ingesteld op een meetfrequentie van 2 minuten. Na iedere meting wordt het instrument goed schoongemaakt. Vervolgens komt het in een houder te liggen samen met enkele andere sensoren. Hierdoor kan een mogelijke afwijking worden vastgesteld. Deze loggers zijn niet recentelijk geijkt. Ze worden daarom slechts gebruikt ter indicatie van de meetomstandigheden.

Temperatuurbereik: $-40^{\circ} \mathrm{C}$ tot $+70^{\circ} \mathrm{C}$

Luchtvochtigheidsbereik: $0-100 \% \mathrm{RH}$

Nauwkeurigheid:

$\pm 0.35^{\circ} \mathrm{C}\left(\operatorname{van}-40^{\circ} \mathrm{C}\right.$ tot $\left.0^{\circ} \mathrm{C}\right)$

$\pm 0.25^{\circ} \mathrm{C}\left(\right.$ van $0^{\circ} \mathrm{C}$ tot $\left.+70^{\circ} \mathrm{C}\right)$

Luchtvochtigheid $\pm 3 \%$ 


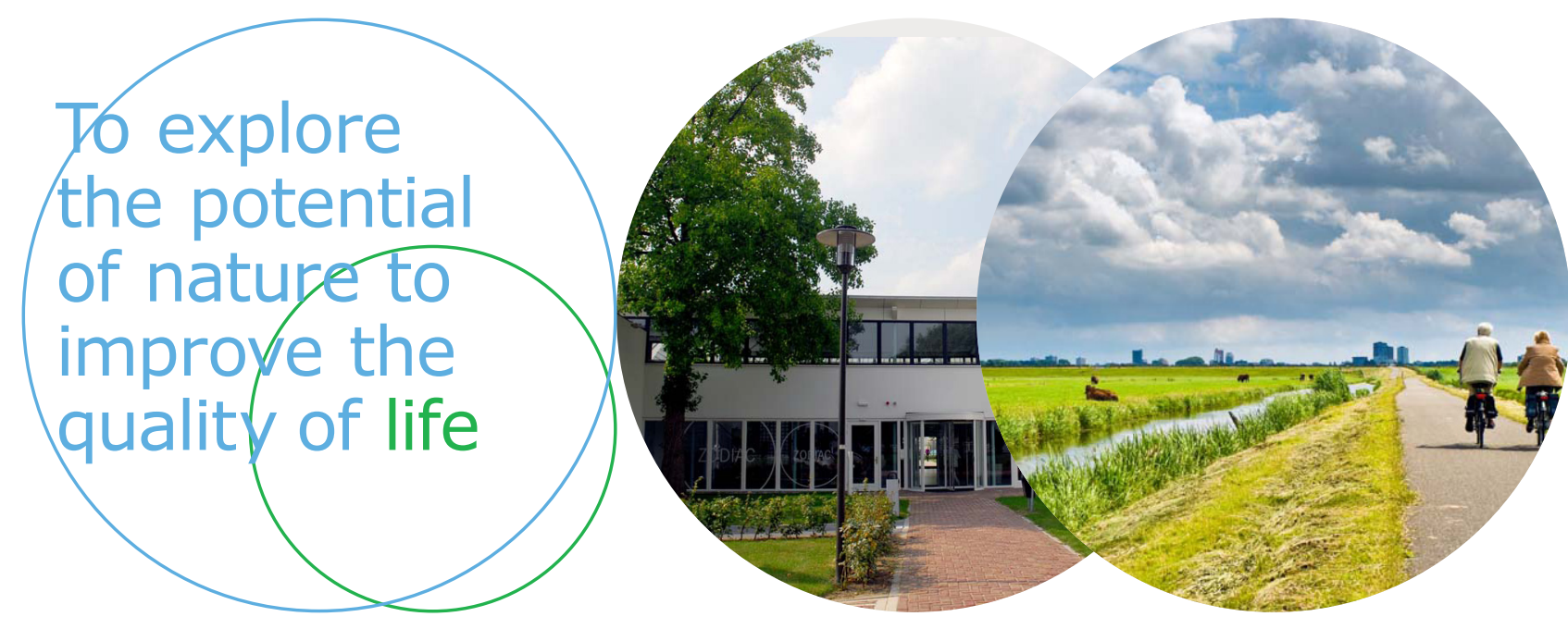

Wageningen Livestock Research Postbus 338

$6700 \mathrm{AH}$ Wageningen

T 0317483953

E info.livestockresearch@wur.nl www.wur.nl/livestock-research
Wageningen Livestock Research ontwikkelt kennis voor een zorgvuldige en renderende veehouderij, vertaalt deze naar praktijkgerichte oplossingen en innovaties, en zorgt voor doorstroming van deze kennis. Onze wetenschappelijke kennis op het gebied van veehouderijsystemen en van voeding, genetica, welzijn en milieu-impact van landbouwhuisdieren integreren we, samen met onze klanten, tot veehouderijconcepten voor de $21 \mathrm{e}$ eeuw.

De missie van Wageningen University \& Research is 'To explore the potential of nature to improve the quality of life'. Binnen Wageningen University \& Research bundelen 9 gespecialiseerde onderzoeksinstituten van Stichting Wageningen Research en Wageningen University hun krachten om bij te dragen aan de oplossing van belangrijke vragen in het domein van gezonde voeding en leefomgeving. Met ongeveer 30 vestigingen, 6.500 medewerkers en 10.000 studenten behoort Wageningen University \& Research wereldwijd tot de aansprekende kennisinstellingen binnen haar domein. De integrale benadering van de vraagstukken en de samenwerking tussen verschillende disciplines vormen het hart van de unieke Wageningen aanpak. 